Jelena Anđelković Grašar,

UDK: 75.05.021.33 ;

The Institute of Archaeology, Belgrade

904:75.052"652"(497.11)

jelenandjelkovic@gmail.com

ID: 195907596

Emilija Nikolić,

Original research article

The Institute of Archaeology, Belgrade

Dragana Rogić,

Received: August 29, 2011

The Institute of Archaeology, Belgrade

Accepted: September 05, 2011

\title{
SYMMETRY OF THE ICONOGRAPHY OF SURFACES AND SPACES FROM THE VIMINACIUM TOMBS G 160, G 5517 AND G 2624
}

\begin{abstract}
As a pictorial principle, symmetry played an important role throughout the whole ancient period, and has remained a significant principle in art right into the modern era. With the knowledge that different artistic workshops consisted of real masters and their associates, it is certain that they had considerable artistic knowledge. In the familiar repertoire of ancient scenes and motifs, painters experimented with elements and principles not only to produce good art work, but also to reach different, or to reinforce existing, meanings. That is why symmetry was an integral part of complicated afterlife compositions from the late antique and early Christian tombs. In this paper, three tombs from Viminacium will be explored as examples of various forms of symmetry, not only in the iconography of painted surfaces, but also in the tomb's space, which, in the context of the afterlife, could be observed as an alternative reality, arranged using strict canons.
\end{abstract}

KEY WORDS: SYMMETRY, ICONOGRAPHY, SPACE, TOMB, VIMINACIUM, PAINTING.

\section{INTRODUCTION}

The word symmetry originates from the Greek language and it signifies uniformity, a lovable disposition of the whole. Symmetry is the universal principle of nature, the most important principle of harmony both in the universe and in art. It played a basic role in classical Greek and Roman art and during the renaissance and neo- classic periods. ${ }^{1}$ However, it has also been one of the most important pictorial principles in contemporary artistic movements. In some periods it was deliberately neglected, ${ }^{2}$ but it is certain that it has been used in art from its very beginnings as one of

1 It is a well known formulation of Johann Joachim Winckelmann from his famous work "Thoughts on the Imitation of Greek Works in Painting and Sculpture (1755)" regarding "noble simplicity and quiet grandeur".

2 For instance baroque or rococo.

* The article results from the project: IRS - Viminacium, Roman city and military legion camp - research of material and non material culture of inhabitants by using the modern technologies of remote detection, geophysics, GIS, digitalisation and $3 D$ visualisation (no 47018), funded by Ministry of Education, Science and Technological Development of the Republic of Serbia. 

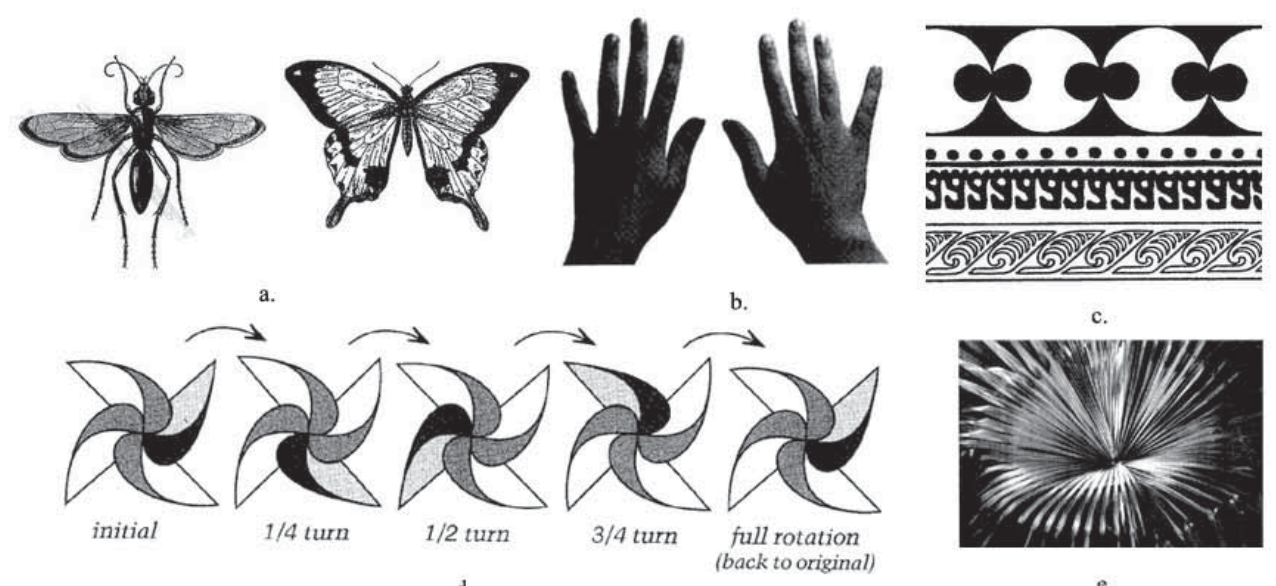

d.

e.
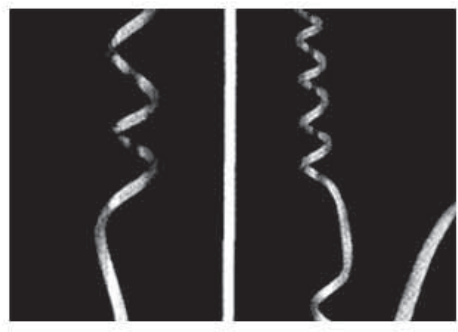

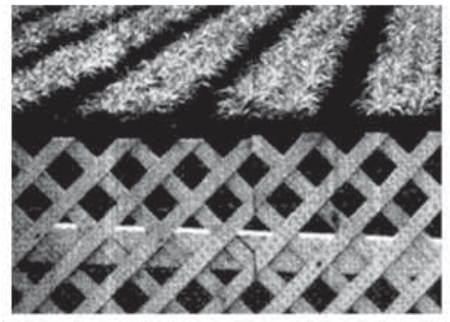

g.

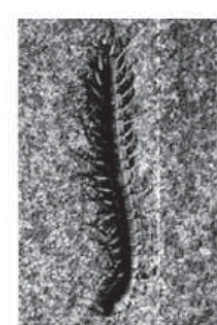

$\mathrm{h}$
Fig. 1a.

Bilateral symmetry - examples of insects. (according to: Hargitai and Hargitai 1994, 18)

Fig. 1b.

Right hand, left hand symmetry - example of human hands. (according to: Hargitai and Hargitai 1994, 28)

Fig. 1c.

Translational symmetry - examples of different ornaments. (according to: Hargitai and Hargitai 1994, 124)

Fig. 1d.

Rotational symmetry - example of a pinwheel.

the basic principles of natural creation, and therefore recognised as an indication of a good work of art. $^{3}$

One of the best known symmetry types used in the arts is geometrical symmetry. According to a contemporary interpretation of the term, symmetry originates from the use of differ-

3 Vitruvius dedicated the whole chapter to the symmetry of building in his third of ten books on architecture: "The design of a temple depends on symmetry, the principles of which must be most carefully observed by the architect". (Morgan 1914: 72.) (according to: Hargitai and Hargitai 1994, 38)

Fig. 1e.

Radial symmetry - example of a plant. (according to: Hargitai and Hargitai 1994, 68)

Fig. 1f.

Spiral symmetry - examples of the plants. (according to: Hargitai and Hargitai 1994, 152)

Fig. $1 \mathrm{~g}$.

Ornamental symmetry - example of a fence. (according to: Hargitai and Hargitai 1994, 177)

Fig. 1h.

Repetitive symmetry - example of a centipede. (according to: Hargitai and Hargitai 1994, 134)

ent transformations of a specific figure which are thus mapped to create its own copy. The position, size or shape of the basic figure can be changed in the copies, but if any of these features remain unchanged, the figures are symmetrical. Among others, the aforementioned transformations are translation, rotation and reflection. Symmetry is almost never perfect. One of the aspects of imperfection is dissymmetry, apropos combined symmetry where one figure is symmetrical in its major features, but also displays a slightly disturbed 
symmetry in some other features. Asymmetry represents a complete absence of symmetry, while antisymmetry is present when the figure is symmetrical in one of its characteristics, while some others are the complete opposite. (Јадрешин Милић 2008: 86-87)

Different types of symmetry depend on the transformational processes under which a figure is changing. Bilateral symmetry is when two halves of an object or a being reflect a mirror image to each other, i.e. a reflection of each other. (Hargitai and Hargitai 1994: 2) In bilateral symmetry the object has only one mirror plane, so this symmetry is actually only one case of mirror symmetry, which means the presence of one or more mirror planes. (ibid: 53) (Fig. 1a) Right hand, left hand symmetry happens when two objects, which do not need to be symmetrical themselves, appear in a pair, positioned next to each other as an object and its image in the mirror. (ibid: 28) (Fig. 1b) Translational symmetry is the repetition of a motive, without changes, by shifting it a constant distance. (ibid: 124) (Fig. 1c) Rotational symmetry occurs when an object is rotated around its axis in a process that consists of several steps. The rotation is repeated several times, and can result in the object returning to its starting position. (ibid: 39) (Fig. 1d) Radial or cylindrical symmetry represents a type of combined symmetry which occurs as a result of a large number of object repetitions around a defined point (rotational symmetry), and its reflection so that, in the end, the shape created from many identical, but rotated objects, represents a circle. (ibid: 68) (Fig. 1e) Spiral symmetry represents a kind of a symmetry of similarity, (Јадрешин - Милић 2008: 92) apropos translation followed by rotation, where their volumes are changing gradually and constantly. ${ }^{4}$ (Fig. 1f)

Within the scenes from Viminacium tombs, one can notice the formation of a rhythm, with parts of the scene set in translational symmetry,

4 Spiral can be connected with the golden ratio. See: Livio 2003: 116-123; Hargitai and Hargitai 1994: 160-164. by way of repetition of the geometrical figures thus creating decorative patterns with crossing lines. This style can be referred to as ornamental symmetry. (Weyl 1952: 83-115) (Fig..1g). By combining translation with rotation and reflection, repetitive symmetry emerges. (Hargitai and Hargitai 1994: 131) (Fig.1h)

Mirror and right hand, left hand symmetry dominates both in art and in nature, and has been most widely represented in visual arts from ancient Egypt to modern days. Rotational, ${ }^{5}$ translational ${ }^{6}$ and ornamental ${ }^{7}$ types of symmetry are also widespread, especially in architecture and the applied arts. (Voloshinov 1996: 110)

\section{SYMMETRY OF ICONOGRAPHY OF PAINTED SURFACES}

When art became a profession, painters were hired to decorate public or private buildings. They started to carefully consider which elements could be used to create an image in a more aesthetic manner. Elements of a good composition are: form, colour, light and dark and expression, which are obtained by the careful use of line, surface, symmetry, balance, contrast, colour, shading, texture, modelling etc. Thus in a work of art, symmetry can be used as symmetry of lines, surfaces or bodies. ${ }^{8}$ (Vasić 1968: 27-29) Using various symmetry types, even ancient painters were able to create different shapes of the same motif, the same motif in a diverse range of appearances and with different meanings.

\footnotetext{
5 Rotational symmetry of the twelfth order, associated with the number of angels, is quite popular in Christian architecture.

6 Translational symmetry forms the basis of borders, fences, etc.

7 Ornamental symmetry is the philosophical core of all Moslem ornamentalism.

8 The aesthetical phenomenon of symmetry is an expression and feeling of balance and tranquility. Psychology and anthropology determine symmetry as an integral part of mans perception of the world. (McBeath et al. 1997: 217-223; Washburn 1999: 547-562)
} 


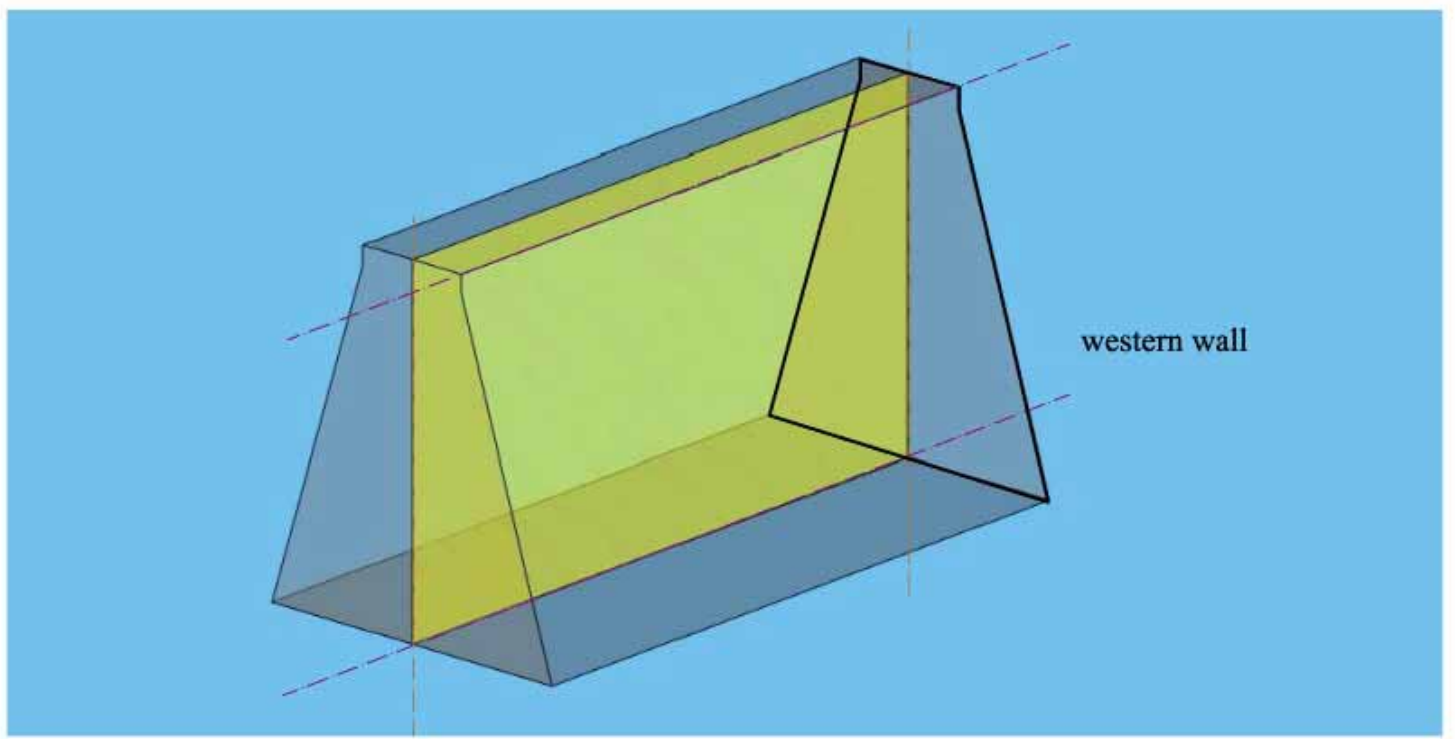

Fig. 2. Trapezial end walls (eastern and western) and rectangular, inclined lateral walls (southern and northern) in the described tombs with the plane of symmetry of the tomb space. (Schemes by Emilija

Nikolić)

The aim of this paper is to examine various symmetry types used in the paintings of Viminacium's tombs, but also the connection between symmetry usage and the possible influences on the motif repertoire and the tomb's programme, narrative or symbolism. "It is important to note that exact symmetry hardly ever exists in art, since nature itself seems to avoid strict symmetry and produces slight flaws in its ideal laws. Thus, the phenomenon of approximate symmetry in art exists both in the conscious attempts of an artist to overcome the aesthetic coldness of ideal symmetry, and in the subconscious, given that approximate symmetry is also a fundamental law of nature." (Voloshinov 1996: 111-112)

The three Viminacium tombs ${ }^{9}$ which will be studied in terms of symmetry possess the usual arrangement of walls within the space: two trapezial end walls (eastern and western) and two rectangular and inclined lateral walls (southern and northern). (Васић 1907: 83-91) (Fig. 2)

9 Tombs G 5517 and G 2624, with fresco copies, are reconstructed at the location next to the tomb G 160 which is in situ with original frescoes. This type of fresco presentation provides an insight into the links between symmetry, iconography and symbolism within the tomb's space.

\section{“Tomb with cupids", G 160}

Tomb G-160 (Korać 2007: 125-140, 186188), with its original frescoes, is found at Viminacium necropolis Pirivoj, and presented in situ. (Fig. 3a and Fig. 3b)

\section{Southern and northern wall.}

Offering scene. ${ }^{10}$ In this scene one can see bilateral symmetry in the depictions of the male and female servants, which is seen in the frontal depiction of any human form. (Fig. 4) This type of symmetry is also present in the motifs of a cup and a plate. Each of them is placed in a central position in relation to its field, so that the fields themselves display the attributes of bilateral symmetry. Although these motifs are not mutually the same, owing to the direction of both bodies toward a common point, (i.e. the western wall of the tomb), the fields do stand mutually in left and right hand symmetry.

Peacock. ${ }^{11}$ There is a visible bilateral sym-

10 One of the typical scenes in pagan funerary art. (Đurić 1985: 161-174)

11 Peacocks are popular motive both for pagan and Chris- 

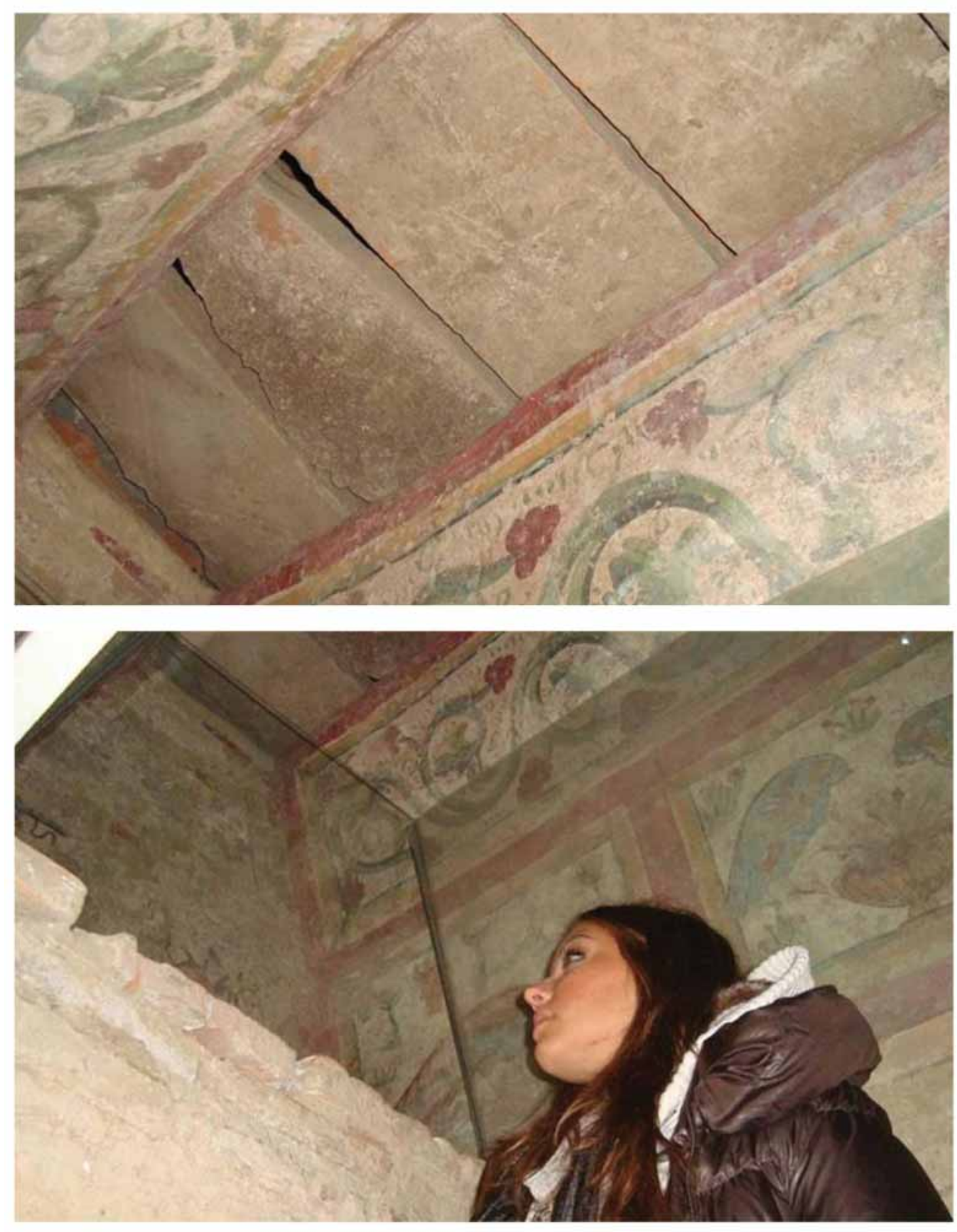

Fig. 3a. In situ presentation of the tomb G 160. (Photos by Jelena Anđelković Grašar) 
metry in the single depictions of a calathos, flowers and plants, as well as in the tails of the peacocks which are stretched across the diagonal of both rectangular fields. (Fig. 5) The flowers in the calathos are positioned in radial symmetry, while ornamental symmetry occurs in the depiction of the texture of the calathos. The eyes on the peacocks' tails are bilaterally symmetric by nature, and are depicted using the process of translational symmetry along the tail. The mutual arrangement of the calathos, and the flowers and plants disposition, originate from the right hand, left hand symmetry, as well as from rotational symmetry. The field on the northern wall of the tomb possesses all the qualities of right hand, left hand symmetry, but if the peacock's tail is observed as an important motif of this scene, then it can be seen to contain an element of bilateral symmetry too. As regards the same field on the southern wall, it consists of total bilateral symmetry. Two fields depicting the scenes with peacocks, on the southern and northern wall, are not completely the same and do not have an identical arrangement of the motifs of calathos, flowers and plants. However, these two fields can be considered symmetrical - a form of right hand, left hand symmetry, due to the mutual symmetry of the peacocks which are the central motifs of the scenes. Owing to this symmetry, within the whole space of the tomb, the peacocks can be observed as if they flank the main, western wall. ${ }^{12}$

Scene with the birds over the kantharos. Within this scene one can notice right translational and hand, left hand symmetry in the mutual position of the birds and flowers, as well as bilateral, ornamental, and radial symmetry within individual depictions of the kantharos and flowers. (Fig. 6) Radial symmetry can be noticed in the radial direction of the branches and the flower within the kantharos. Ornamental symmetry is present

tian art. (Anđelković et. al. 2011: 231-248)

12 In the same way peacocks flank the mistress of the " $\mathrm{Pa}-$ gan tomb" G-2624. (Korać 2007: 69-72; Anđelković et. al. 2011: 236) in the depiction of the texture of kantharos. The birds have small differences in the posture of their bodies; however, this does not reduce the symmetry of the scene. The entire scene has bilateral symmetry, and the two fields are equally placed in an arrangement of right hand, left hand symmetry. They possess the most perfect single symmetries of all the motifs and scenes, as well as the most perfect symmetry of a field, compared to all the other fields in the tomb.

Grapevine. ${ }^{13}$ Considering that this motif occupies the whole field, and in view of its symmetry, it can be regarded as a scene possessing bilateral symmetry, but also consisting of several smaller, different motifs, created with the use of various symmetry types. (Fig. 7) The basic line of direction of the grapevine displays bilateral symmetry, while other lines equally fall into the right hand, left hand symmetry category. Individual motifs, such as grape clusters and vine leaves, possess bilateral symmetry. The tendrils of the vines naturally have spiral symmetry. The overall motif can be obtained from several smaller motifs, which include the same right hand, left hand symmetry as well as translational symmetry. The two fields with these scenes are both bilaterally symmetrical, although the middle leaves and tendrils of the vine, through which the axis of symmetry of each scene runs, are not bilaterally symmetrical as motifs, and the scene on the northern wall has one of the tendrils turned in the opposite direction from that which would be expected. Within the tomb space, the fields are positioned in a right hand, left hand symmetrical pattern in relation to each other.

13 More about symbolism of the motive in: (Рогић, Анђелковић 2011: 102) 


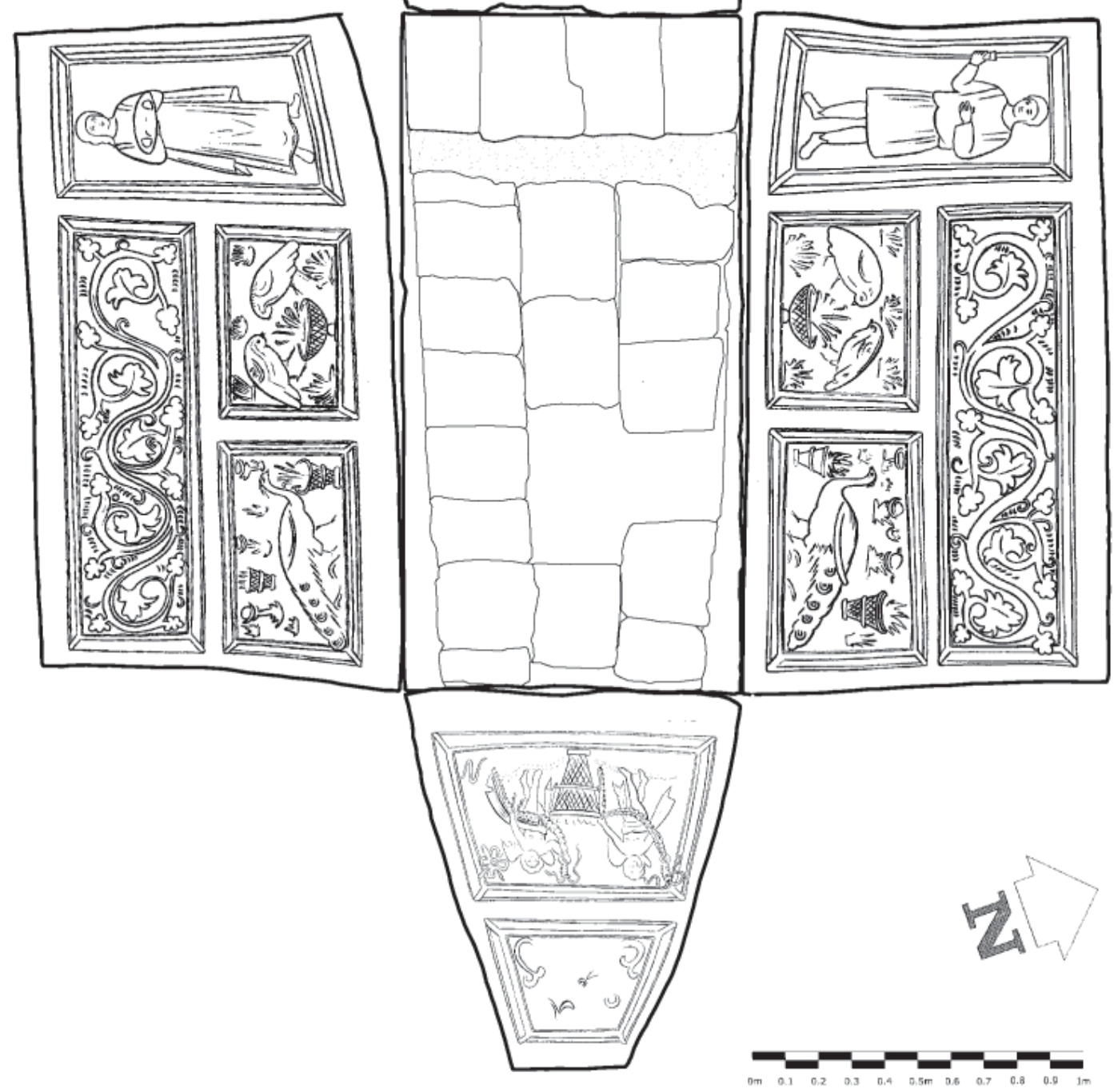

Fig. 3b. Four walls of the tomb G 160 with its frescoes. (Schemes by Dragana Rogić) 
SYMMETRY OF THE OFFERING SCENE - northern and southern wall
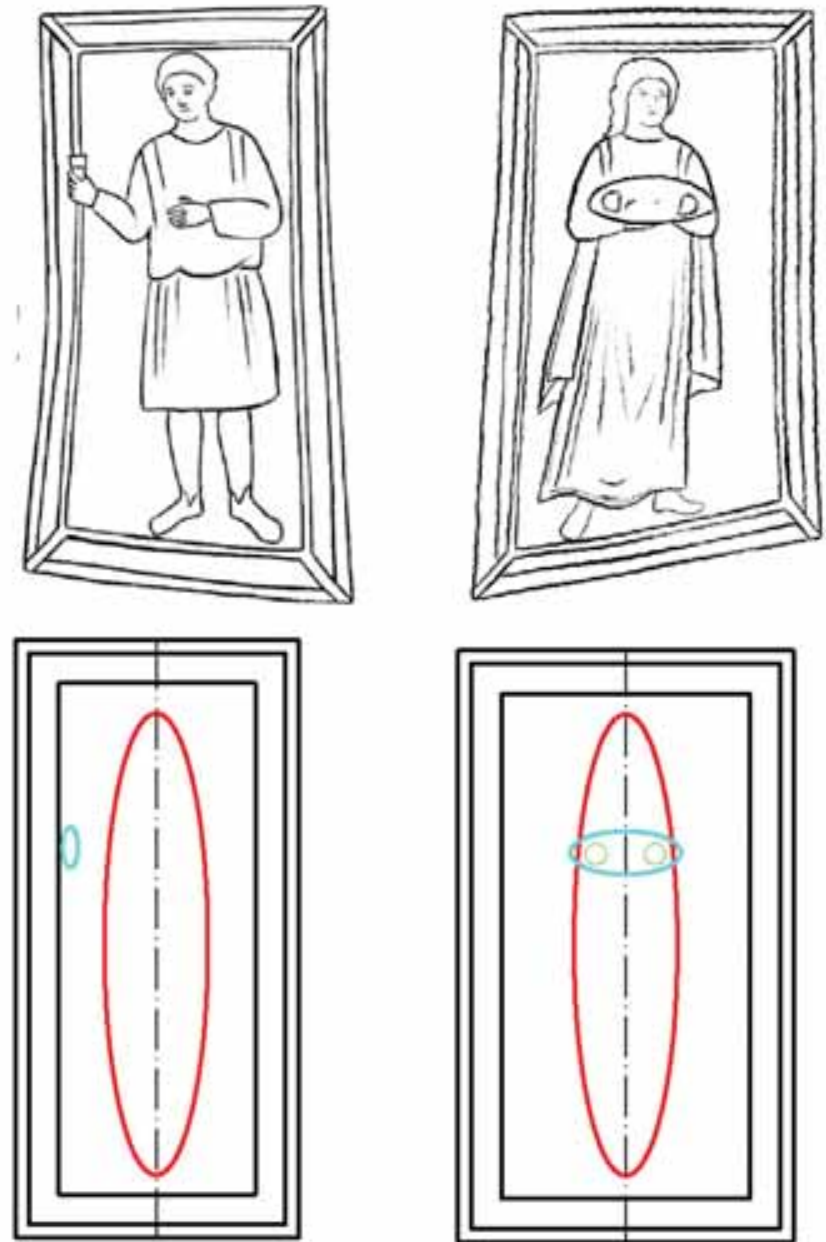

northern wall

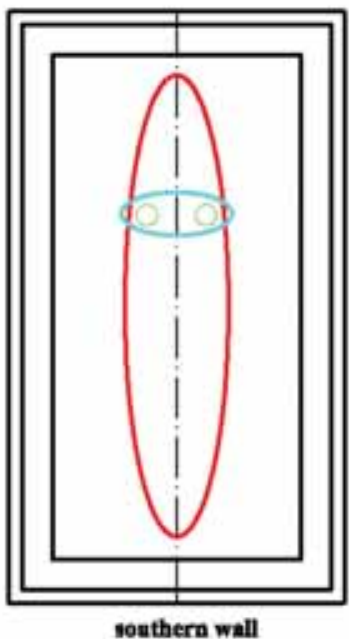

Bilatenal symmetry of the scene that originate from servants (human figures) symmetries (the axes of symmetries are vertical lines that divide the fields into two equal segments)
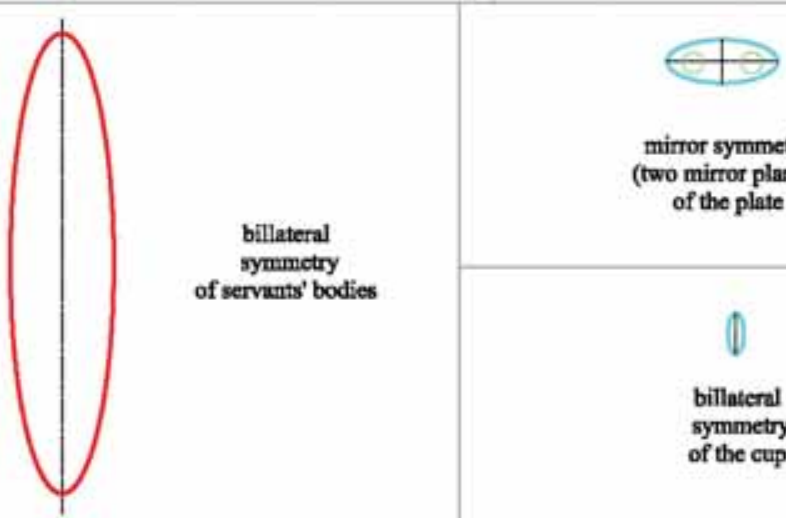

mirror symmetry

(two mirror planes) of the plate

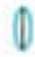

billateral

symmetry

of the cup

Fig. 4. Symmetries of the offering scene in the tomb G 160. (Schemes by Emilija Nikolić) 


\section{Eastern wall.}

Scene with the cupids. ${ }^{14}$ In this scene, the cupids possess bilateral, and the calathos possess bilateral and ornamental symmetry. (Fig. 8) The garlands are formed using repetitive symmetry with a combination of translational and right hand, left hand symmetry. The flower in the upper right corner is formed with rotational symmetry of its petals, and, itself has mirror symmetry with two mirror planes. ${ }^{15}$ The position of the cupids' bodies, particularly the legs, gives them a mutual right hand, left hand symmetry, although it is interrupted with the opposed position of their hands, heads and garlands. The whole scene, i.e. the field, possesses bilateral symmetry, with the central bilaterally symmetric calathos between the cupids and its radially positioned plants and ornamental symmetry surface. All this suggests that the image in the trapezium above the cupids, which is damaged and therefore unrecognisable, probably possessed the same types of symmetry. This could lead us to conclude that the whole eastern wall could have had a common type of symmetry - bilateral symmetry.

\section{Western wall.}

The reconstruction of the scenes and motifs from this wall is almost impossible, but it can be concluded that it had bilateral symmetry within its fields, along with right hand, left hand symmetry in the fields with scenes which contained several motifs, or bilateral symmetry in the scenes with only a single motif.

14 Although cupids were a popular motive in ancient decorative art, there are only few examples of cupids in funerary art. (Minns 1915: 143-147; Rostovtzeff 1919: 144-163; Venit 1999: 641-669)

15 This four petal flower in cross form shape is a very well known motif in late antique and early Christian funerary art. The unanswered question is whether painters had a natural floral pattern to work from or they created it from their imagination. Today, floral symmetry is a very well documented field in biology. (Рогић, Анђелковић 2011: 94-95, 100; Giurfa et al. 1999: S41-S50; Endress 1999: S3-S23)

\section{“Christian tomb”, G 5517}

Tomb G 5517 (Korać 2007: 33-62, 157168 ) is a reconstruction and, therefore, not in its original location. The presented frescoes are replicas of the originals kept at the National Museum in Požarevac. The difference between this and other tombs of the same type is in the narrative of the decoration: the scenes are composed as individual panels, but are arranged to be read as a story in a clockwise direction. (Fig. 9a and Fig. 9b)

\section{Northern wall.}

Scene with earthly horseman. In front of the reconstruction of what is thought to have been the entrance to the tomb, there is the first scene describing an earthly horseman, being followed by a lion. (Fig. 10) This scene is set in the frieze formed by two red stripes. Within this frieze it is clear to see that the scene is full of rhythm. Looking at the main figures, there is not any visible symmetry. The figures of the rider and the lion are subordinated to the principles of movement, rhythm and dynamics. However, within the main antique, and especially late antique idea of horror vacui, all other motifs in the scene are arranged in the background of the main motifs, following some of the symmetry types. The floral motifs from the earthly landscape and the rider's face all possess bilateral symmetry, some possess radial symmetry, and they are all set around the main scene mostly in a variation ${ }^{16}$ of translational symmetry, which is upgraded, especially in this place, to ornamental symmetry that fits into the decorative scheme and context of rhythm. So, from here all pictorial elements and principles suggest that the next element of the story is the paradise scene with peacocks and the tree of life on the right.

16 As previously mentioned, translational symmetry is the repetition of a motif, "without changes", creating a rhythm. "Without changes", cannot be applicable to this painting, because of the possibilities of the fresco technique and the lack of space within the tomb, so we again can refer to the use of approximate symmetry. (Voloshinov 1996: 111-112) 


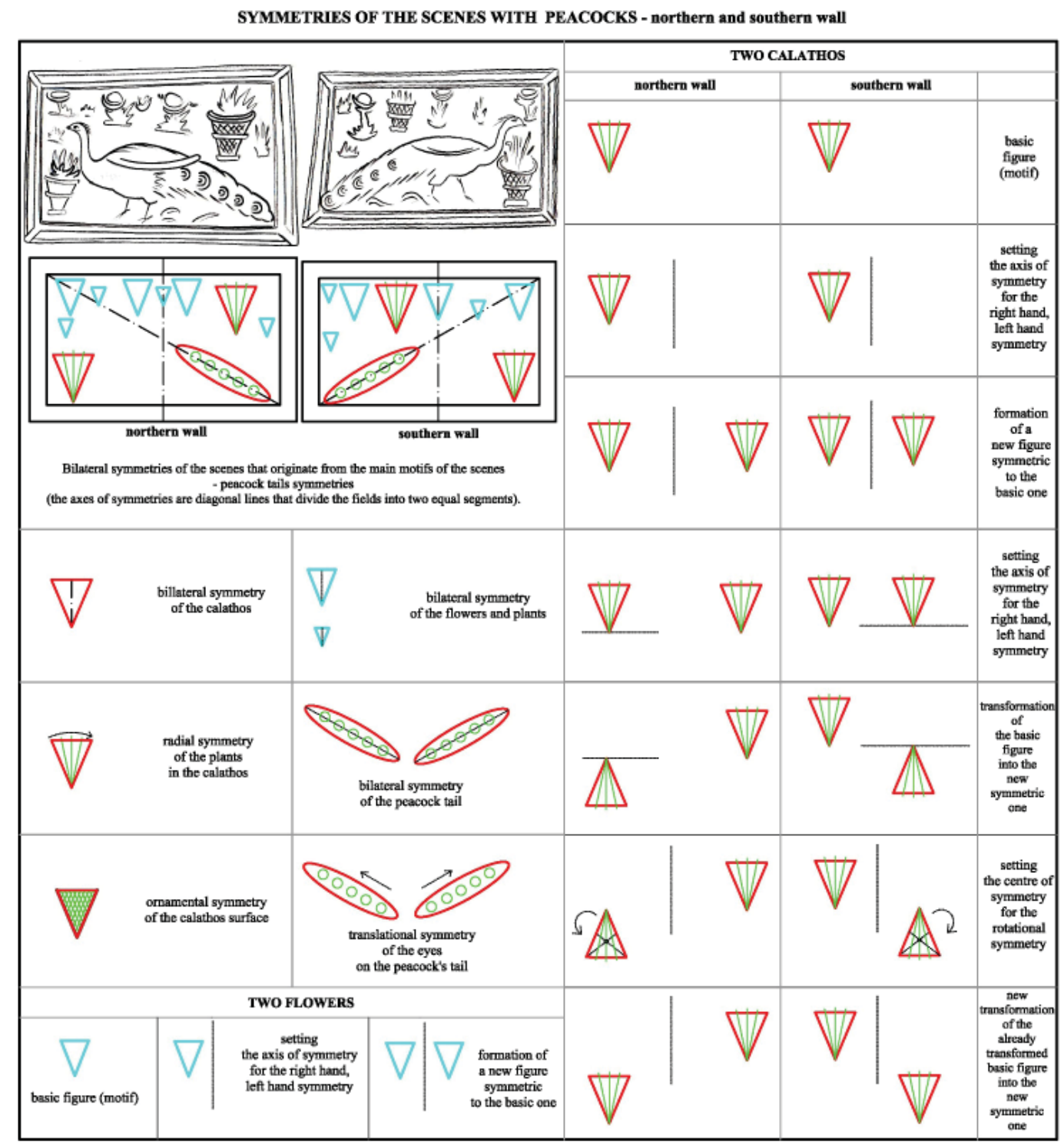

Fig. 5. Symmetries of the scenes with peacocks in the tomb G 160. (Schemes by Emilija Nikolić)

The whole scene is, therefore, without any particular ruling symmetry, but it can be said that all the symmetries of its motifs and the horror vacui contribute to the balance of the scene.

\section{Eastern wall.}

Paradise scene. This scene, as with the previous one, is set in the frieze formed by two red stripes. (Fig. 11) In this scene, the kantharos is positioned as a focus and as an axis, not only for the symmetry of the peacocks, but for all other motifs, i.e. for the entire scene. The kantharos itself possesses bilateral symmetry, while the aqua vitae is depicted with a sort of radial symmetry. In the upper part of the scene, the aqua vitae becomes an axis for the motifs of the tree of life, which are positioned in right hand, left hand symmetry. One of the most common scenes in the late antique and early Christian period presents peacocks flanking a kantharos. Usually, in such a scene, the peacocks ${ }^{17}$ are depicted in almost per-

17 As previously mentioned, the eyes on the peacock's 
SYMMETRIES OF THE SCENES WITH BIRDS - northern and southern wall

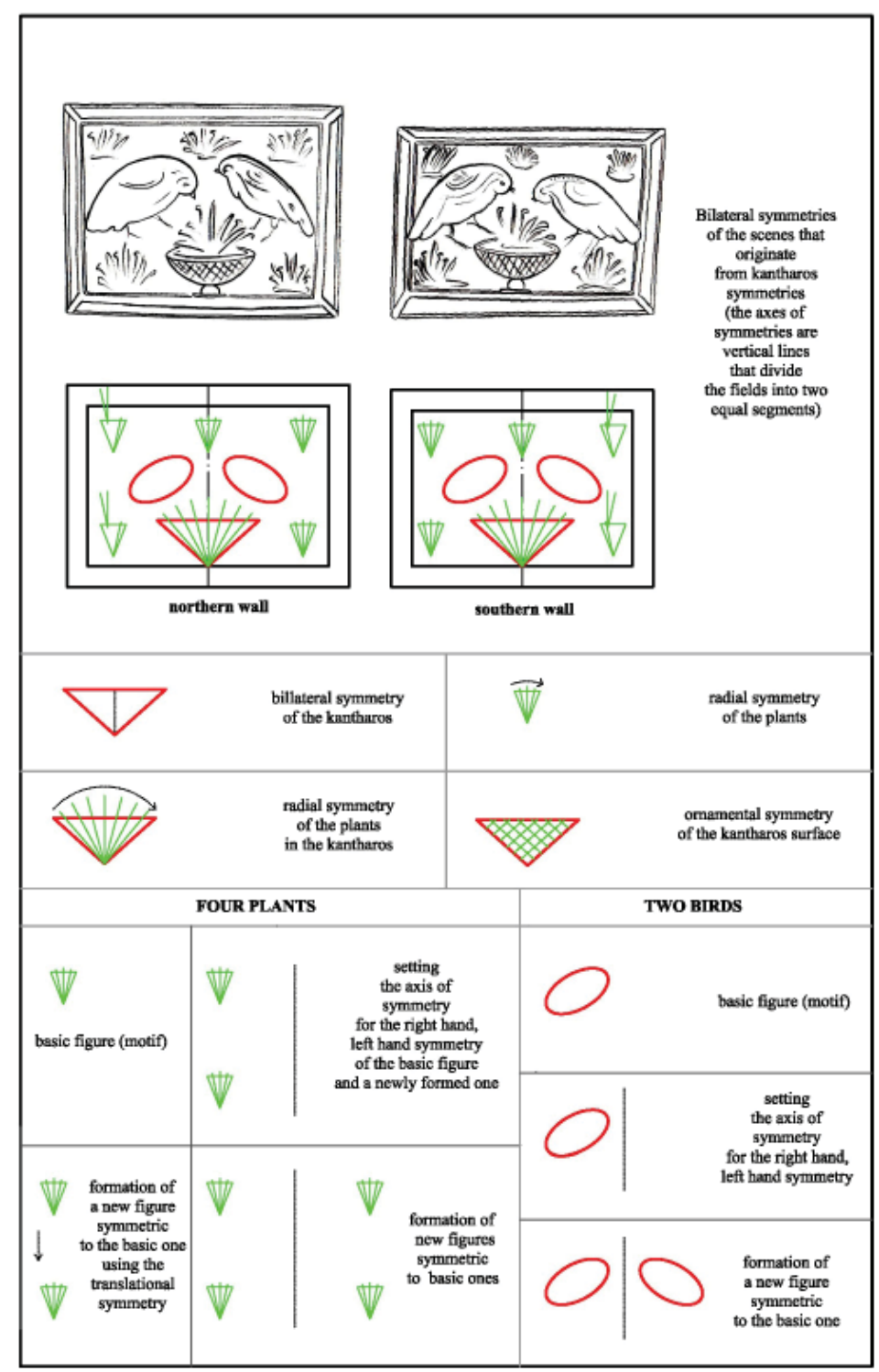

Fig. 6. Symmetries of the scenes with birds in the tomb G 160. (Schemes by Emilija Nikolić)

fect symmetry, while here the right hand, left hand symmetry has been distorted by the turned head of the peacock on the right (Anđelković et al. 2011: 240). With regard to this irregularity, the small element of dissymmetry is of great importance to the overall understanding of the painting's narrative, as it encourages us to look to the right and continue reading. The eyes on the peacocks' tails

tail are bilaterally symmetric by nature, and here depicted with the process of translational symmetry along the tail. are depicted using the translational symmetry along the tail. Collectively, the whole scene can be considered to have been created using bilateral symmetry.

At this point we should notice that a similar scene with imperfect (referred to as either approximate or natural) right hand, left hand symmetry of peacocks over an amphora can be seen on the western wall of the Viminacium tomb G 5464.

(Korać 2007: 21, 156.) 
SYMMETRIES OF THE SCENES WITH GRAPEVINES - northern and southern wall

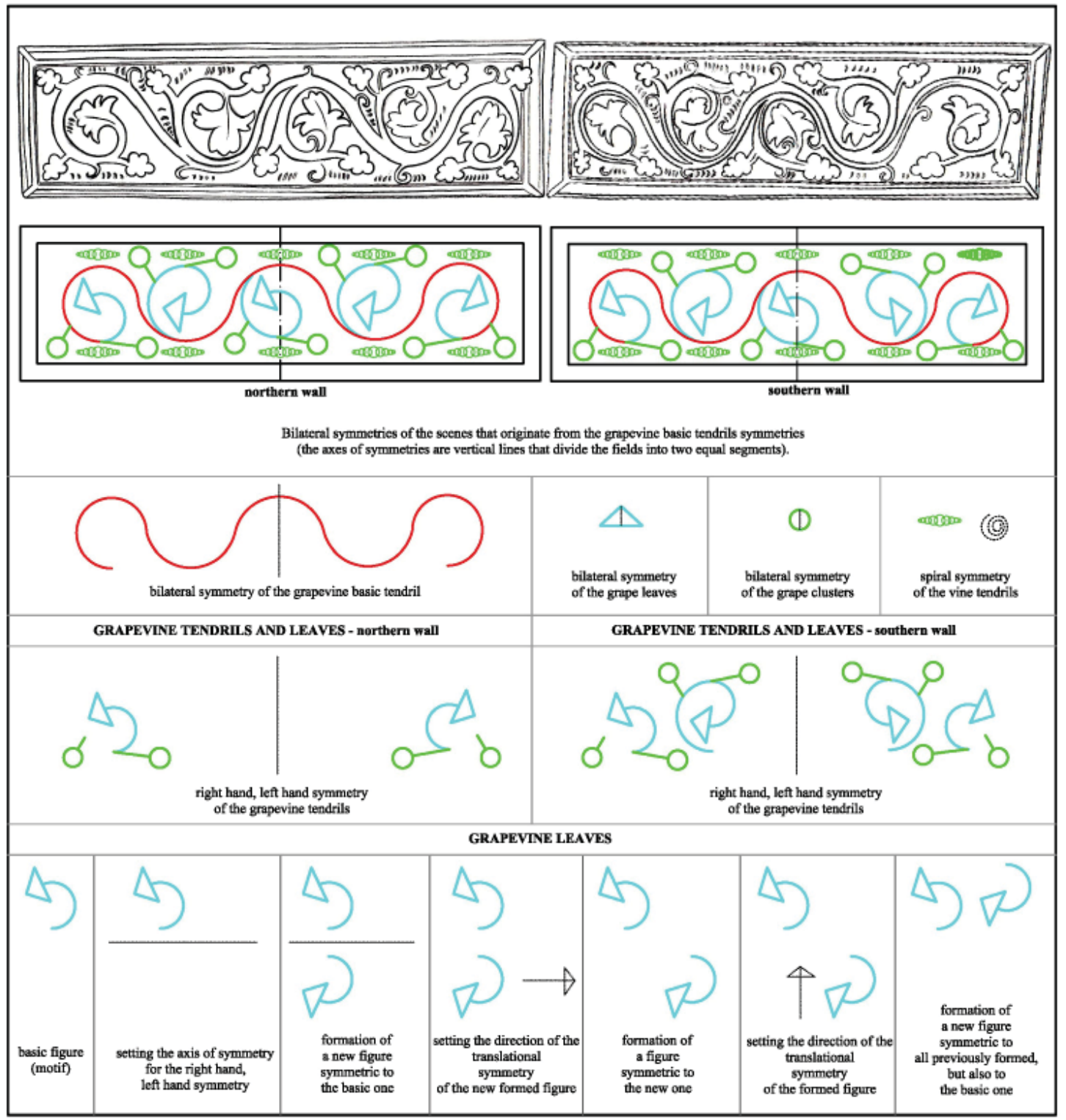

Fig. 7. Symmetries of the scenes with grapevines in the tomb G 160. (Schemes by Emilija Nikolić)

\section{Southern wall.}

Scene with heavenly horseman. The main figures depict the heavenly horseman, who is followed by a dog and in front of whom there is a leopard. (Fig. 10) This "moving" frieze is again set between two red stripes. Trees and floral motifs are set in a heavenly landscape mostly conforming to translational, radial and ornamental symmetry, but not in exactly the same way as in the northern wall's scene. All the figures again gesture to the right of the scene, where Christ's monogram is depicted.

\section{Western wall.}

Christ's monogram. Unlike the three aforementioned panels, where two red stripes form the frieze, the main scene here is located within the trapezial frame of red borders. (Fig. 12) 
SYMMETRY OF THE SCENE WITH CUPIDS - eastern wall

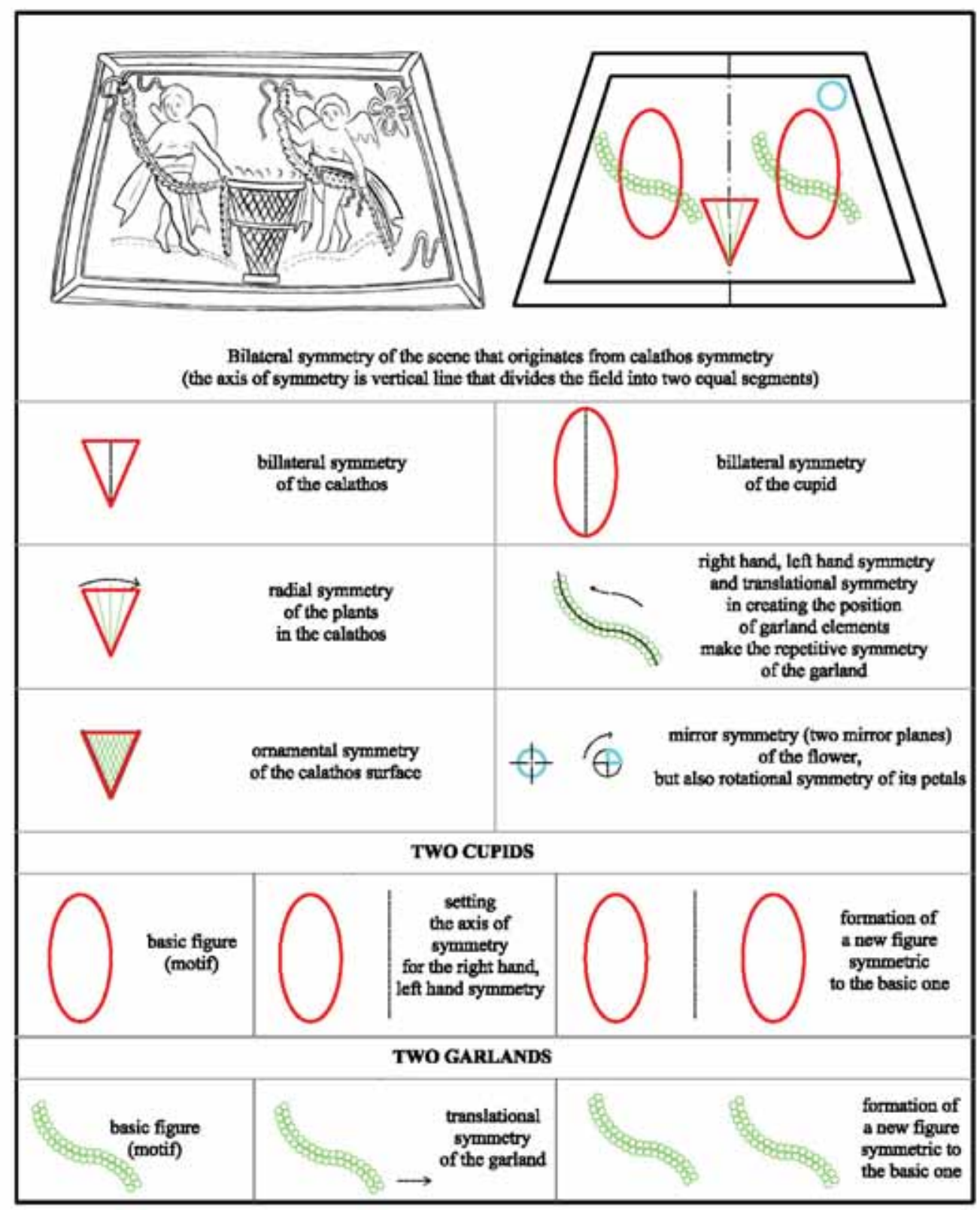

Fig. 8. Symmetries of the scenes with cupids in the tomb G 160. (Schemes by Emilija Nikolić)

The monogram itself is composed of straight lines of the letters $\mathrm{X}(\mathrm{Hi})^{18}$ and $\mathrm{P}$ (Ro), crossed in the middle, resembling rays and, as a result, we can speak here of imperfect rotational symmetry as well as imperfect bilateral symmetry. The sign is surrounded with a laurel wreath, which consists of small leaves, repeating in a certain rhythm, which is created using a combination of bilateral and translational symmetry, which combine to represent repetitive symmetry. Within the monogram, the apocalyptic letters A (alpha) and $\Omega$ (omega) are positioned according to right hand, left hand symmetry. Below the monogram there are some freely painted red linear motifs arranged in trans-

18 This letter has bilateral symmetry. 
lational and ornamental symmetry. ${ }^{19}$ The entire scene is created with bilateral symmetry.

\section{Northern, eastern and southern walls}

Grapevine. $^{20}$ Except the western wall, where the Christ's monogram occupies most of the wall surface, making it important as the focus of the composition, all three other walls contain the frieze above the upper red stripe, with one of the most typical ancient motifs - the grapevine. (Fig. 11) Since the greater part of this frieze is not well preserved (except a small part on the eastern side) it is hard to make a judgement regarding the symmetry. As in many other depictions of the same motif, the basic line of the grapevine's direction possesses bilateral symmetry, while the other lines possess imperfect right hand, left hand symmetry. The clusters are a set of blue and red points, rather than represented as a fruit with any kind of symmetry. The vine leaf possesses bilateral symmetry. The tendrils of the vine, naturally, already have spiral symmetry, and here, they are depicted very vividly. The motif of the grapevine can be obtained from several smaller, mutually identical motifs, in a process which includes right hand, left hand symmetry as well as translational symmetry. We can say that eastern scene with grapevine possesses bilateral symmetry that originates from the symmetry of the main tendril, but imperfect, because of the irregular position of the grape clusters and vine leaves. If the friezes on the northern and southern side had been better preserved, we would, maybe, be able to speak about the mutual relationship of all three grapevine scenes in terms of symmetry.

A similar arrangement of the grapevine can be seen on the northern and southern walls of the Viminacium tomb G 5464 (ibid,: 22, 156). It is interesting to note that symmetries from the northern grapevine scene here correspond to the one on

19 It can not be said with any certainty what kind of symmetry is applied here, since this part of the scene is not well preserved.

20 See reference 13, and compare with "Grapevine" from the tomb G 160. the southern wall, both displaying right hand, left hand symmetry. On the eastern wall of the same tomb there is a good example of natural symmetry (such is the symmetry of the grapevine and its tendrils) applied in basic, symbolic shapes, such as spirals. Here again, the spiral can be observed as the essential form, from which painters formed the shape of the grapevine. As an ancient shape, the spiral form (vine, ivy, snail or seashell) symbolically alludes to an evolution of a natural force or condition, it is an open and optimistic motif and it possesses a cosmic symbolism of fertility. (Gerbran, Ševalije 2004: 863-866)

\section{“Pagan tomb" G 2624}

The tomb G 2624 (Korać 1993: 107-122; idem. 2007: 69-100, 168-185) is also a reconstruction and contains copies of the original frescoes that are kept at the National Museum in Požarevac. (Fig. 13a and Fig. 13b)

\section{Western wall.}

Portrait of a lady. Considering that the west wall in pagan tombs usually held a portrait of the deceased, it is believed that the portrait of a young woman on the west wall represents a portrait of a deceased woman. (Fig. 14) The entire decoration programme of this tomb is subordinated to this image. Here, the symmetry plays an important role in the composition of the scene. In the first place, as is known, the human figure possesses bilateral symmetry, which is of great importance here because of the meaning and appearance of the woman's figure. In accordance with her luxurious dress and beautiful jewellery, it can be concluded that she belonged to the higher ranks of society. To express her noble solemnity and seriousness, the painter depicted her frontally and almost perfectly symmetrically. The almost perfect bilateral symmetry of the lady is only broken with her raised right hand and her looking to the side. In addition, the entire 
composition is symmetrical and set within a red frame. Blue stripes behind the woman's shoulders are positioned by way of right hand, left hand symmetry. The blue halo behind her head is positioned bilaterally symmetrical and the garlands are in the symmetry of left and right hand in relation to the centre of the scene. Symmetry was also used in the smaller details, such as in the fine bottle in the woman's hand, which is of bilateral symmetry, or in the repetitive, radial, translational and ornamental symmetries visible in the decoration of the cloth, the collar as well as the pearls in the necklace. The whole scene is created with bilateral symmetry.

\section{Eastern wall.}

Offering scene. ${ }^{21}$ This scene, shown on the opposite wall to the scene depicting the woman, contains the figure of a male servant, depicted with a plate and some ritual bread, together with floral motifs in the background. (Fig. 15) This male servant is depicted in full figure, in motion, but positioned diagonally within the field described by the red borders. The plate in his hands is depicted using mirror symmetry with two mirror planes. Here, the human body is depicted in bilateral symmetry, but diagonally positioned. Although the flowers ${ }^{22}$ and the ivy leaves, which are bilaterally symmetrical in nature, are repeated on both sides of the background space, we cannot talk of perfect right hand, left hand symmetry, but of several symmetries used in the same way as the calathos, flowers and plant symmetries in the peacock scene from the G 160 tomb. Bilateral symmetry of the whole scene is lost with the diagonally positioned male servant body, but, the pallium is positioned in opposite rotated direction, so the balance of the scene is achieved.

21 Compare with the "Offering scene" from the tomb G 160 , and reference 10 ;

22 These flowers, as well as the flowers in the background of the peacocks on both of the walls, are of the four petal type and of cruciform shape, as mentioned above. They have natural bilateral and rotational symmetry. See reference 15 .

\section{Northern and southern walls.}

Peacocks. ${ }^{23}$ The peacocks painted on the walls of the tomb are similar, but not identical. ${ }^{24}$ (Fig. 16) The scenes are framed with red borders. The peacock on the northern wall stretches over the entire wall, dividing the background wall diagonally. On the lower part of the divided space, there is an amphora, depicted using bilateral symmetry, which stands on a linear motif on the ground, which is also divided in two parts, displaying right hand, left hand symmetry. In the upper part of the divided space, there is a garland, depicted using blue and red lines. Since four petal flowers are freely arranged in the background of the scene, without any order or rhythm, here we can talk of a combination translational and rotational symmetries. The peacock on the southern wall, also diagonally divides the background space into two parts. In the lower part, there is an amphora depicted using bilaterally symmetrical, but, unlike the amphora on the northern wall, there is only one part of a freely painted linear motif. In the upper part there are two crossed garlands, depicted only in red. As their parts can be observed as mirror images, it can be said that the garlands are depicted using left and right hand symmetry, but created by the repetition of the smaller motif using translational symmetry. Four petal flow$\mathrm{ers}^{25}$ are depicted in the background of the whole scene, arranged in a similar way to those on the northern wall. Imperfect bilateral symmetry of the scenes originates from the peacock tails symmetries which are its main motifs.

23 See footnote 11 and compare with "peacocks" from the tomb G 160 .

24 Their mutual symmetry within the tomb's space, will be discussed later.

25 See footnotes 22 and 15. 


\section{SYMMETRY OF THE ICONOGRAPHY OF SPACE}

Primarily, symmetry was used as an initial pictorial principle, equivalent to the proportion and geometry of a composition. In contemporary $\operatorname{art}^{26}$ and design, on the subject of symmetry, science has developed a new theory of "dynamic symmetry". (McWhinnie 1986: 241-245) The development of the idea of symmetry grew from the comprehension of external geometrical symmetry to an increased understanding of the internal structure of the universe, accessible only to the mind. (Voloshinov 1996: 109) So, the principle of symmetry developed from an artistic to a scientific principle, ${ }^{27}$ where it occasionally becomes the concept for an individual theory. (Dion 1991: 511517) This is why the principle of symmetry can be applied in the case of tomb's space, not only with regard to the regularity of all other elements, but also as a symbolic connection between elements, iconography and space. ${ }^{28}$

Aside from the fact that ancient artists took care with, and knew about, symmetry as an important principle in the formation of an image, it is more than certain that they were creators of conceptual programs and contextual meanings. Therefore, the arrangement of the motives, scenes, compositions and pictorial elements which created them went beyond the mere creation of iconography. The artists who painted walls of tombs were also contemplating their meaning within the specific space and their mutual relationships. This is why the position and orientation of the scenes and motifs were crucial for the creation of a threedimensional space for the afterlife within a sacred

26 Orientated towards abstract and conceptual art. 27 We have already mentioned psychology, anthropology, and biology, but there are sciences such as physics, chemistry, molecular processes and atomic physics, electronics, etc. which are also connected with this principle.

28 With the idea of collecting the individual scenes and motifs into the universal image of cosmic drama. (Цветковић-Томашевић 1978: 87-101). space $^{29}$ such as a tomb. So, the aforementioned tombs from Viminacium were painted according to a pictorial legitimacy, but there are also noticeable regularities in the plan's design which is symmetrical within the tomb's space.

\section{“Tomb with cupids” G 160}

The northern and southern walls, together display right hand, left hand symmetry. However, if the western wall is the pivot of the iconographical repertoire, that is to say, if the tomb space is comprehended as a visual unity of individual motifs of paradise, the whole tomb gains total bilateral symmetry, i.e. mirror symmetry. (Fig. 17) Mirror symmetry is also important in a symbolical context, because it alludes to another world, i.e. the afterlife, (Gerbran, Ševalije 2004: 624-628) which reinforces the symbolism of the individual motifs.

\section{“Christian tomb” G 5517}

Within this tomb, copies of the frescoes were placed in a setting similar to the original one, in order not to distort the correct reading of the iconographical and symbolical story. To understand the meaning of this complex pictorial story, we must actually turn clockwise around our axis, demonstrating the importance of keeping frescoes in their original spatial context. Thus, all four walls become participants of the rotational symmetry of the observer, which occurs in the middle of the tomb's space, on the axis of the observer's body, while one attempts to read the narrative. (Fig. 18) Thus, symmetry, iconography and symbolism, assembled within the tomb's space, provide the viewer with an impression of a "kinetic"

29 In terms of considering some space as sacred we can use methods of hierotopy. See: Lidov 2006: 32, ref. 2 . 
composition, somewhat untypical for ancient art. For the two scenes with horsemen, it can be said that they are positioned using the antisymmetry. If we observe them as sole figures, horsemen are similar to one another in their body movement, head direction and other physical characteristics, but different in their symbolism.

\section{“Pagan tomb" G 2624}

Similar to the "Tomb with Cupids", the northern and southern walls stand in left and right hand symmetry, in relation to the woman whose image is the pivot and axis for the two peacocks in the apotheosis scene. The peacocks are oversized, and this scale was probably meant to reinforce the symbolism (Anđelković et al. 2011: 231-248; Janićijević 2009: 135-143). Again, in the spatial context of the tomb, looking at the peacocks, we can see mirror symmetry. (Fig. 19) The woman (as the mistress of the tomb) appears tranquil and solemn owing to the use of the frontal representation and the vertical and horizontal axes of symmetries, in contrast to the young man (as the woman's servant) on the opposite wall, who is depicted in motion by the use of "diagonal axis symmetry". This tomb space reveals not only the use of skilled painters who were artistically educated, but also many hidden symbolical messages which, as we can see, can be concealed behind an artistic tool such as symmetry.

\section{CONCLUSION}

Most of the fresco-painted tombs from Viminacium are not well preserved, so it is not possible to reconstruct the whole programme and its meaning, or even its symmetry. However, the aforementioned three tombs have all the necessary elements to be comprehended from the perspective of symmetry. Not only did the paint- ers create the motifs within the scenes, then the scenes themselves, and finally the wall compositions, with calculated and meaningful symmetry types, they also obviously took care with the careful use of symmetry in the context of the afterlife symbolism. It is well known in the history of the arts that pictorial elements and principles, such as colour or balance, were very important for image creation..$^{30}$ Our aim in this paper was to point to symmetry as a principle, significant not only for simple pictorial image creation, but also for creating the meaning, content and symbolism of the image. Besides its fundamental usage in iconography, this paper examined the role of symmetry within the tomb's space, as a special artistic, architectural and sacred reality. In this context, images are not only individual motifs, but create a part of a complex scene, which is subordinated to the philosophy of death, and creates an intimate reality of the deceased's afterlife. In such a context, symmetry goes beyond its limits as a principle and becomes a tool for creating architecture, whilst expressing philosophical ideas. Used in the right places, in appropriate measures, it can help us understand the craft and artistic virtue which Viminacium painters possessed.

Translated by: Jelena Anđelković Grašar

30 Also used in terms of symbolism. 


\section{BIBLIOGRAPHY}

Anđelković, J., Rogić, D. and Nikolić, E. 2011 Peacock as a sign in the late antique and early Christian art, Archaeology and Science 6, (2010): 231-248.

Цветковић-Томашевић, Г. 1978

Рановизантијски подни мозаици, Дарданија, Македонија, Нови Епир, Београд: Филозофски факултет, Институт за историју уметности.

\section{Danov, H. and Ivanov, T. 1980}

The Silistra tomb, Antique tombs in Bulgaria, Sofia: Sofia Press.

Dion, E. 1991

Symmetry: A Social Symbol and Two Monuments, Leonardo, Vol. 24, No. 5, (1991): 511-517.

Đurić, S. 1985

Kasnoantičke i ranohrišćanske zidane grobnice u Iliriku (III-VI в.), (neobjavljena doktorska teza): Filozofski fakultet, Univerzitet u Beogradu.

Димитров, Д. П. and Чичикова, М. 1986

Късноантичната гробница при Силистра, София: Бьлгарски художник.

Endress, P. K. 1999

Symmetry in flowers: Diversity and Evolution, International Journal of Plant Sceinces, Vol. 160, No. S6, Development, Function and Evolution of Symmetry in Plants, (1999): S3-S23.

Gerbran, A. and Ševalije, Ž. 2004

Rečnik simbola, Novi Sad: Stylos.

Giurfa, M., Dafni, A. and Neal, P. R. 1999

Floral symmetry and its role in plant-pollinator systems, International Journal of Plant Sceinces, Vol. 160, No. S6, Development, Function and Evolution of Symmetry in Plants, (1999): S41S50.

Hargitai, I. and Hargitai, M. 1994 Symmetry: An Unifying Concept, Bolinas, CA: Shelter Publications, Inc.

\section{Јадрешин - Милић, Р. 2008}

Појам симетрије као универзалног принципа обликовања, Архитектура и урбанизам 22-23, (2008): 85-97.

\section{Јанићијевић, Г. 2009}

Портрет жене из Viminaciuma могући кључ за одгонетање иконографског садржаја античке сепулкралне уметности, Иконографске студије 2 (2008): 135-143.

\section{Korać, M. 1993}

Late Roman Tomb with Frescoes from Viminacium, Старинар (н.с.) XLII (1991): 107-122.

\section{Korać, M. 2007}

Slikarstvo Viminacijuma, Beograd: Centar za nove tehnologije - Viminacium.

\section{Lidov, A. 2006}

Hierotopy. The creation of sacred spaces as a form of creativity and subject of cultural history, in A. Lidov (ed.), Hierotopy the Creation of Sacred spaces in Byzantium and Medieval Russia, Moscow: Indrik: $32-58$.

\section{Livio 2003}

M. Livio, The Golden Ratio: The Story of Phi, The World's Most Astonishing Number, NewYork: Broadway Books.

McBeath, M. K., Schiano, D. J. and Tversky, B. 1997

Three-Dimensional Bilateral Symmetry Bias in Judgments of Figural Identity and Orientation, Psychological Science, Vol. 8, No. 3, (1997): 217223.

McWhinnie, H. J. 1986

A Review of the Use of Symmetry, the Golden Section and Dynamic Symmetry in Contemporary Art, Leonardo, Vol. 19, No. 3, (1986): 241-245.

Mikić, I. 2008

Antropološki osvrt na Pagansku grobnicu G-2624 antičkog Viminacijuma, Archaeology and Science 3 (2007): 37-45. 
Minns, E. H. 1915

Antichnaja Dekorativnaja Zhivopis' na Juge Rossii, Journal of Hellenic Studies 35 (1915): 143147.

Morgan, M. H. (trans.) 1914

Vitruvius the ten books on architecture, Cambridge: Harvard University Press.

\section{Овчаров, Д. П. and Ваклинова, М. 1978}

Рановизантискит паметници от Бьлгария $I V$ VII век, София: Септември.

Рогић, Д. and Анђелковић, J. 2011

Вегетабилни мотиви у касноантичком и ранохришћанском фунерарном сликарству на територији Србије, Ниш и Византија Х, (2011): 85-104.

\section{Rostovtzeff, M. 1919}

Ancient Decorative Wall-Painting, The Journal of Hellenic Studies, Vol. 39 (1919): 144-163.

\section{Васић, М. 1907}

Неколике гробне конструкције из Виминациума, Старинар н.р. II (1907): 67-98.

\section{Vasić, P. 1968}

Uvod u likovne umetnosti; Elementi likovnog izražavanja, Beograd: Umetnička akademija u Beogradu.

\section{Venit, M. S. 1999}

The Stagni Painted Tomb: Cultural Interchange and Gender Differentiation in Roman Alexandria, American Journal of Archaeology, Vol. 103, No. 4 (1999): 641-669.

\section{Voloshinov, A. V. 1996}

Symmetry as a Superprinciple of Science and Art, Leonardo, Vol. 29, No. 2, (1996): 109-113.

\section{Washburn, D. 1999}

Perceptual Anthropology: The Cultural Salience of Symmetry, American Anthropolgist, Vol. 101, No 3, (1999): 547-562.

\section{Weyl, H. 1952}

Symmetry, Princeton, NJ: Princeton University Press.

\section{SIMETRIJA IKONOGRAFIJE POVRŠINA I PROSTORA VIMINACIJUMSKIH GROBNICA G 160, G 5517 I G 2624}

\author{
KLJUČNE REČI. - SIMETRIJA, IKONOGRAFI- \\ JA, PROSTOR, GROBNICA, VIMINACIJUM, SLI- \\ KARSTVO
}

Još je antički čovek znao za pogodnost slike kao medija komunikacije. Kada se njome počeo baviti slikar, te kada je postala dekor, a onda i nosilac složenih poruka, ubrzo su ustanovljena pravila po kojima nastaje. Linija, ton, valer i boja gradili su sliku, ali kvalitet su joj davali simetrija, ravnoteža i volumen. Slikari koji su vladali ovim elementima i principima činili su ih stožerima dobre slike.

Jedan od najznačajnijih likovnih principa je simetrija. Analizirajući fresko slikarstvo grobnica sa Viminacijuma primećuje se da su najzastupljeniji tipovi geometrijske simetrije: bilateralna (simetrija ogledala), rotaciona, translatorna, radijalna, spiralna, ornamentalna i simetrija leve i desne ruke. Pored ideje da se ustanove simetrije koje su vladale u ikonografskom repertoaru grobnica, cilj rada je traganje za uzajamnim vezama između likovnih principa (simetrije) i narativa ili simbolike samih scena i njihovih kompozicija. Zato su izabrane freske iz tri viminacijumske grobnice: „Grobnice sa kupidonima“ G 160, „Hrišćanske grobnice“ G 5517 i „Paganske grobnice" G 2624. Pored pomenutih tipova simetrije korišćenih u građenju slika iz grobnica, zajednička im je i aproksimativna simetrija, tj. nesavršena simetrija, koja je karakteristična i za prirodne simetrične oblike. Posmatrajući simetriju sa savremenog stanovišta, kao pojam karakterističan ne samo za umetnost, već i za nauku, u ovom radu je postavljamo i u kontekst prostora groba, gde je takođe, kao i u ikonografiji slike, imala ne samo karakter principa, već i jaku simboličku ulogu u prostoru namenjenom drugom životu, a gde je zajedno sa motivima, učestvovala u stvaranju druge stvarnosti. Sve ovo dovelo je do zaključka da su slikari Viminacijuma dobro poznavali likovne zakonitosti, te učestvovali ne samo u građenju slike, već i u njenom smeštanju u okviru jednog određenog prostornog konteksta. 

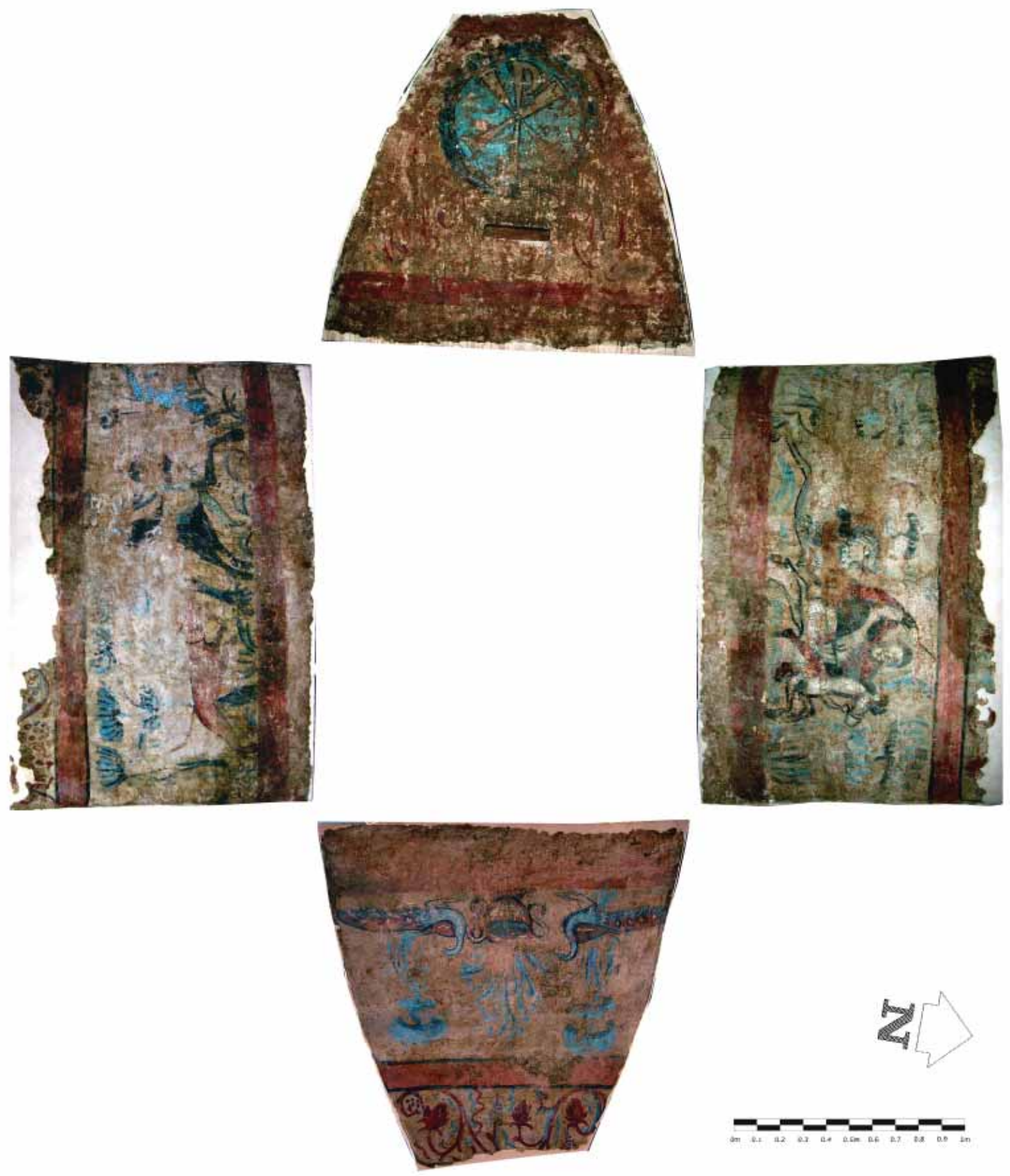

Fig. 9a. Frescoes of the tomb G 5517 presented as individual panels on the walls of the National Museum in Požarevac, here presented as tomb's reconstruction set up in the Archaeological Park of Viminacium. (Photos by Miomir Korać) 


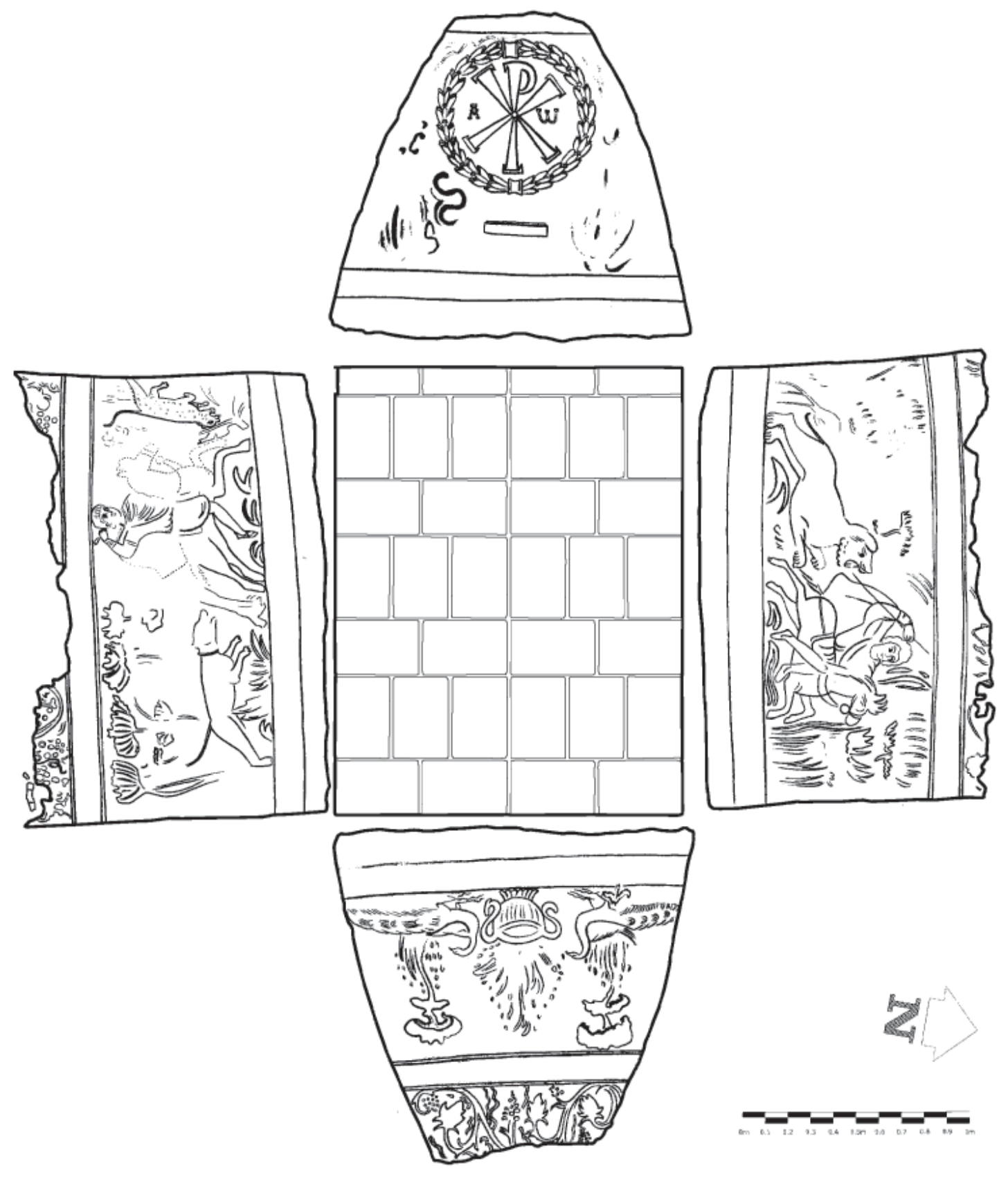

Fig. 9b. Four walls of the tomb G 5517 with its frescoes. (Drawing by Dragana Rogić) 
SYMMETRIES OF THE SCENES WITH EARTHLY AND HEAVENLY HORSEMEN - worthers ned seethere wall

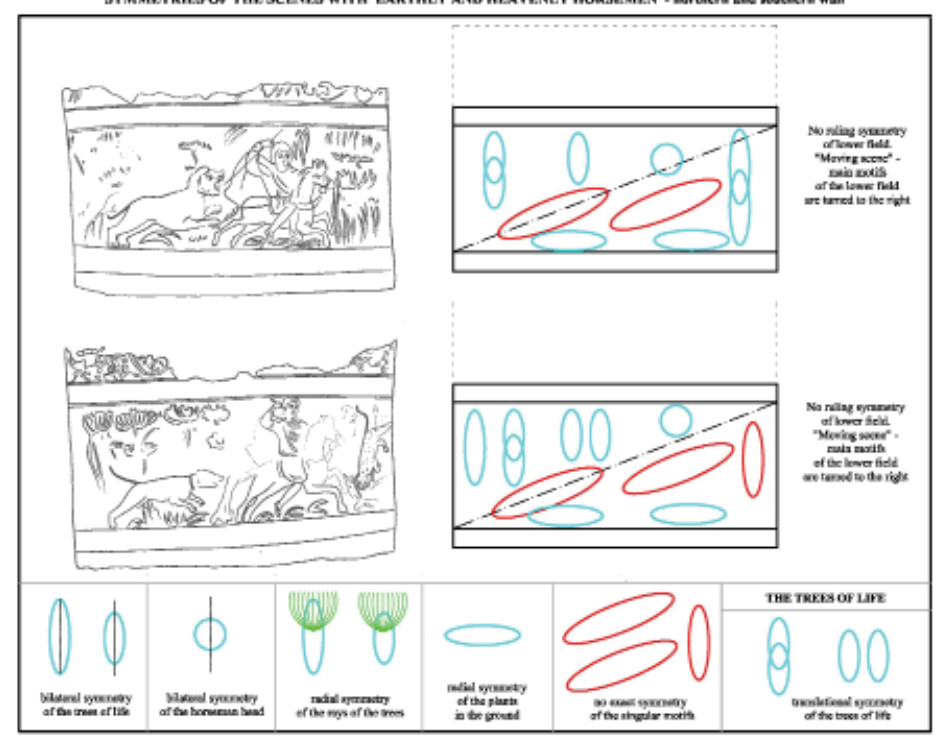

Fig. 10. Symmetries of the scenes with earthly and heavenly horsemen in the tomb G 5517 .

(Schemes by Emilija Nikolić)

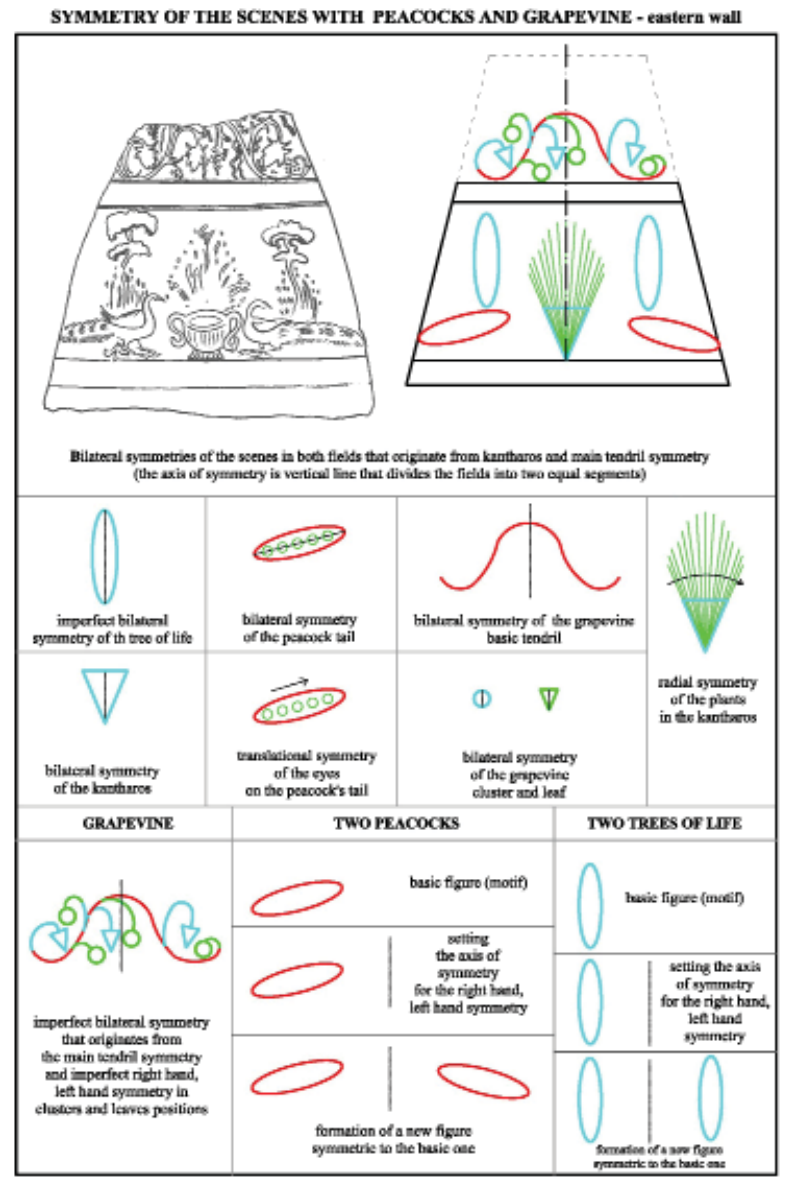

Fig. 11. Symmetries of the paradise scene and grapevine scene in the tomb G 5517.

(Schemes by Emilija Nikolić) 


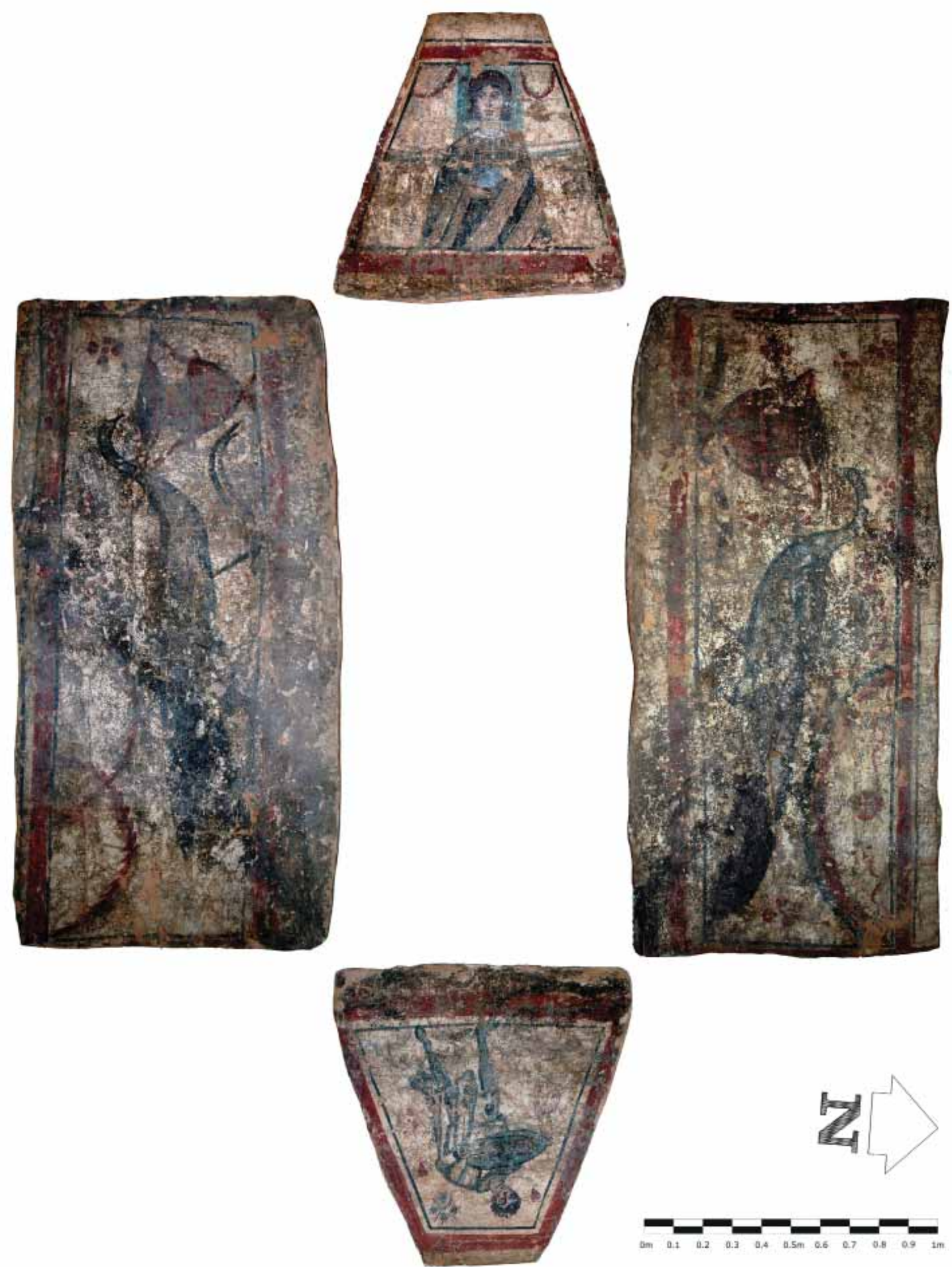

Fig. 13a. Frescoes of tomb G 2624 presented as individual panels on the walls of the National Museum in Požarevac, here presented as tomb's reconstruction set up in the Archaeological Park of Viminacium. (Photos by Miomir Korać) 


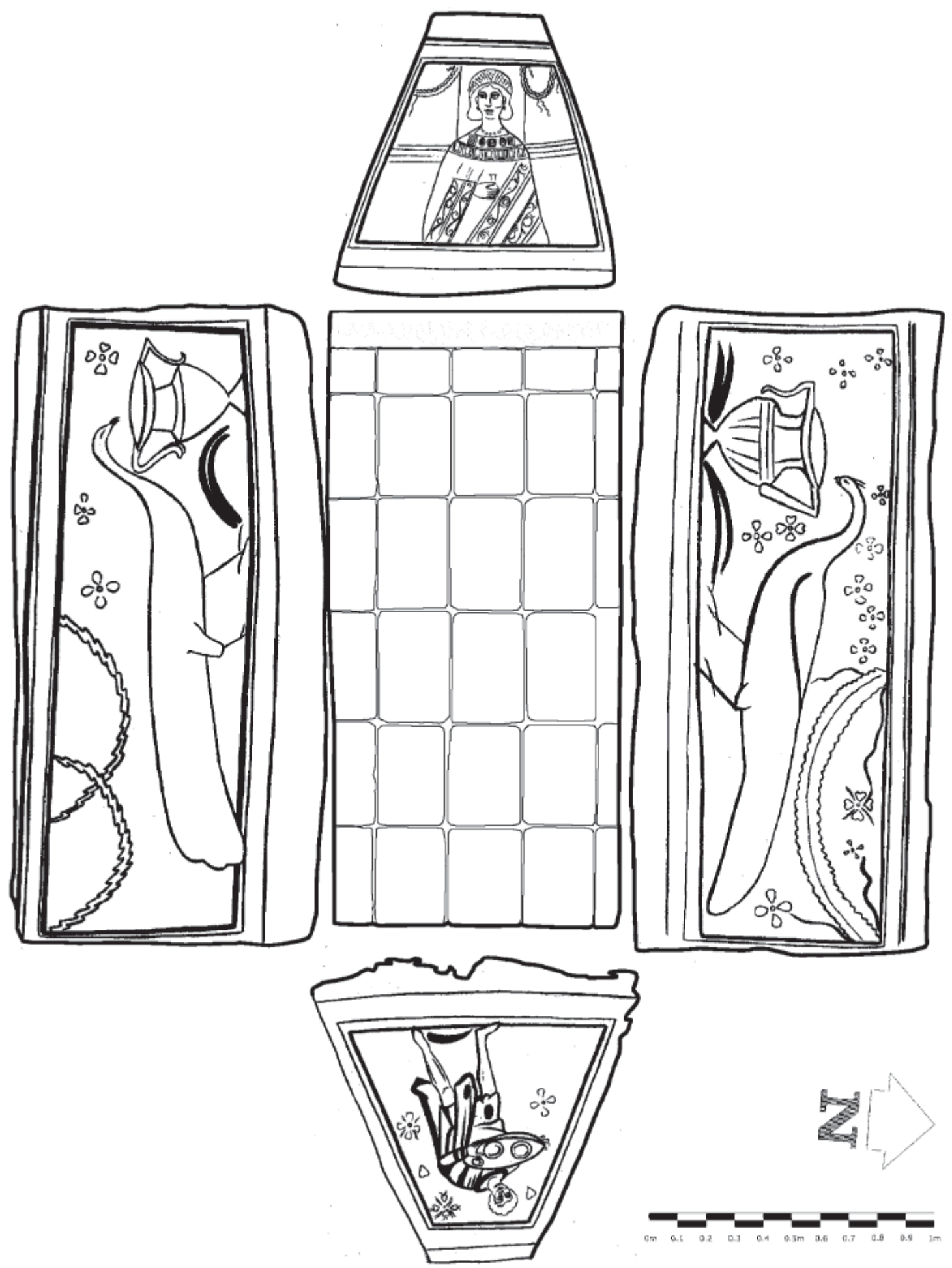

Fig. 13b. Four walls of the tomb G 2624 with its frescoes. (Drawing by Dragana Rogić) 
SYMMETRY OF THE SCENE WTTH CHRIST'S MONOGRAM - western wall
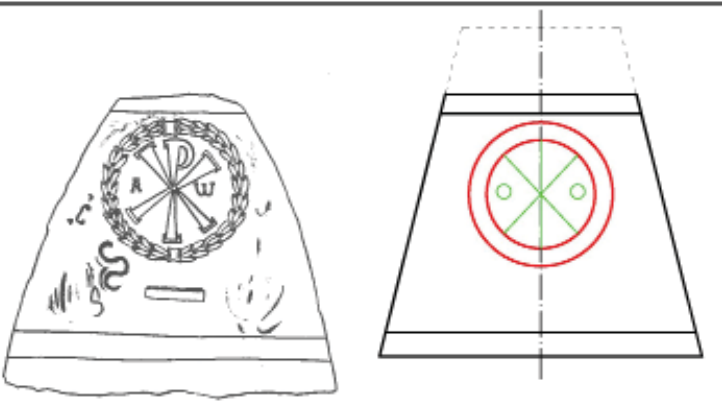

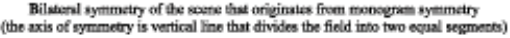
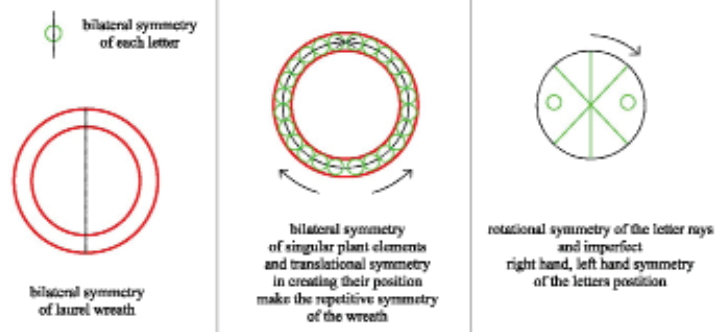

Fig. 12. Symmetry of the scene with Christ's monogram in the tomb G 5517.

(Schemes by Emilija Nikolić)

SYMMETRY OF THE SCENE WITH A PORTRAIT OF A LADY - western wall

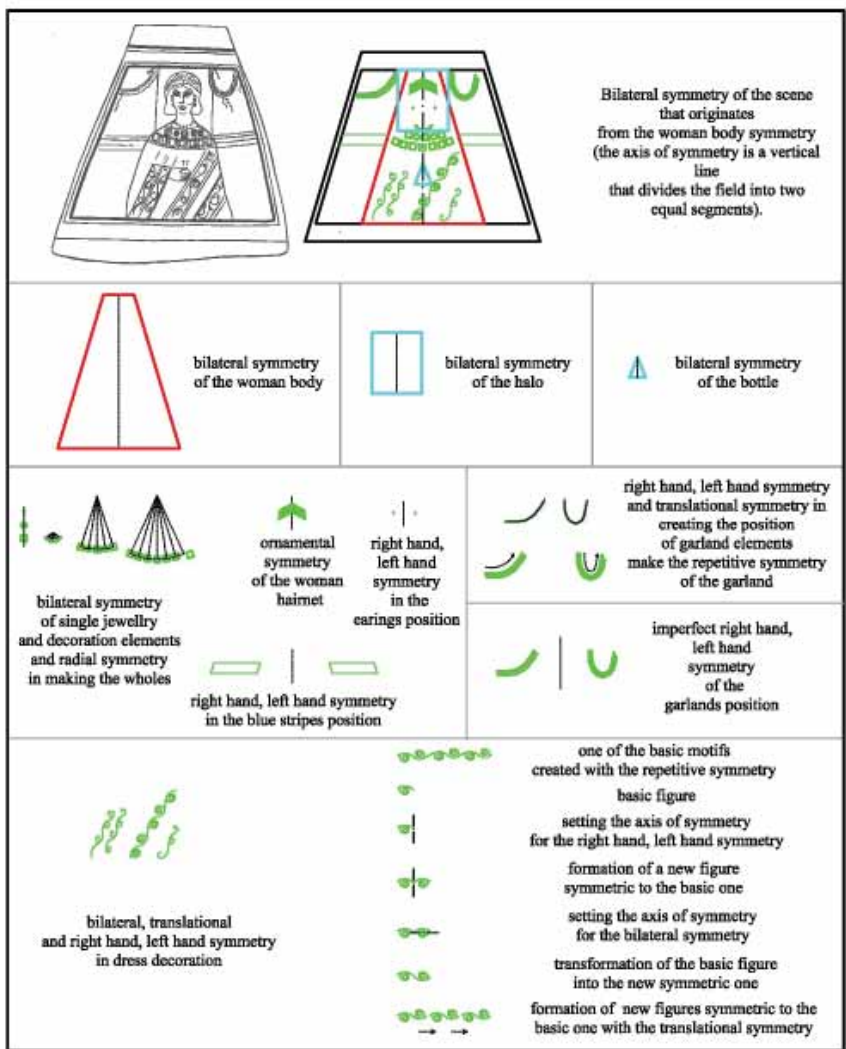

Fig. 14. Symmetry of the scene with a portrait of a lady in the tomb G 5517 .

(Schemes by Emilija Nikolić) 
SYMMETRY OF THE OFFERING SCENE - eastern wall

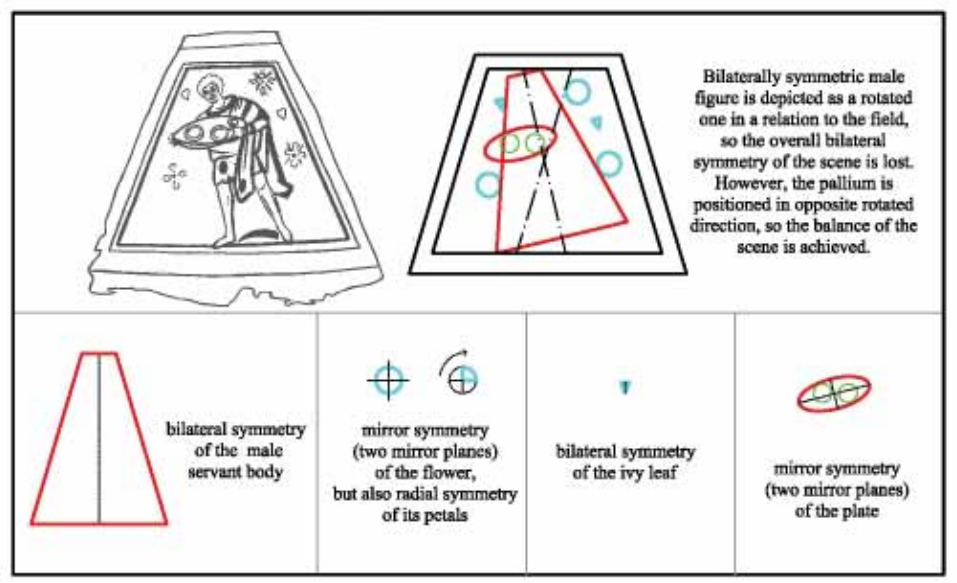

Fig. 15. Symmetry of the offering scene in the tomb G 2624.

Schemes by Emilija Nikolić)

SYMMETRIES OF THE SCENES WITH PEACOCKS - northern and southern wall
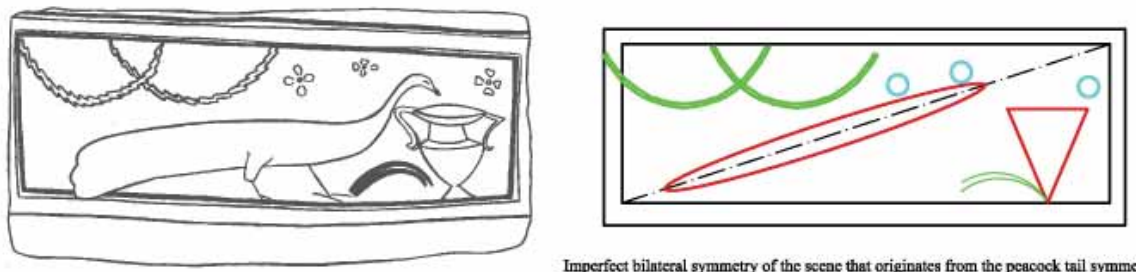

Imperfect biluteral symmetry of the seene that originates from the peacock tail symmetry (the axis of symmotry is a diagonal line that divides the field into two equal segments).
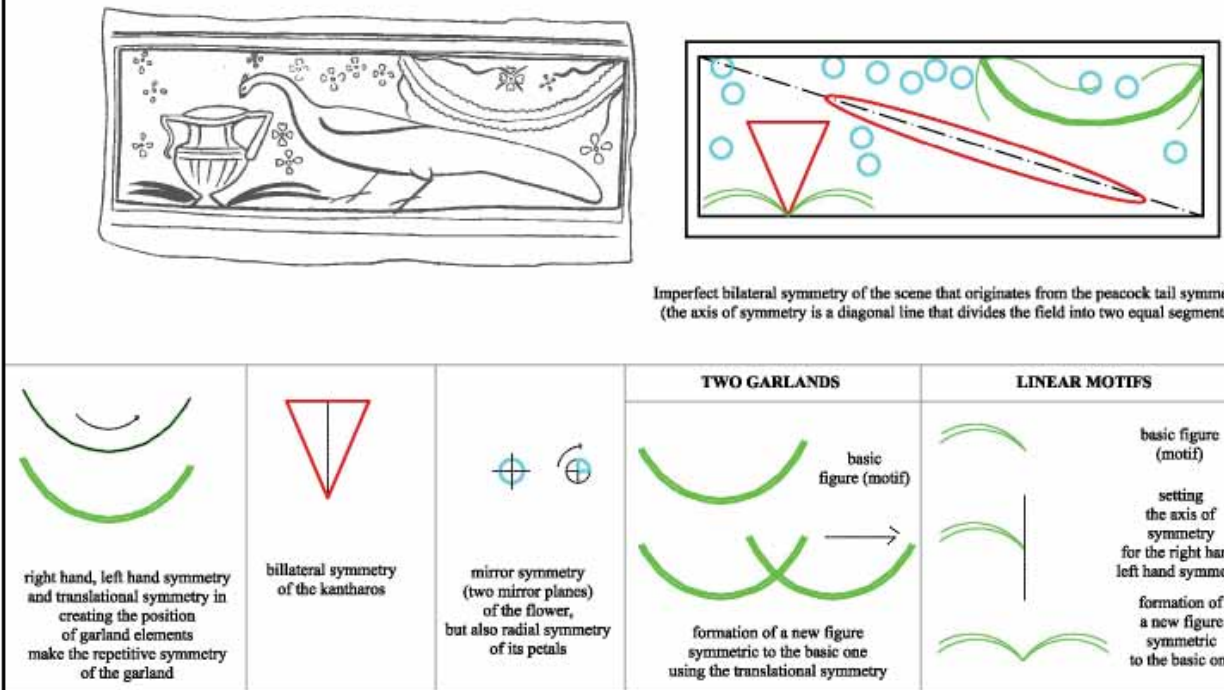

Imperfect bilateral symmetry of the scene that originates from the peacock tail symmetry (the axis of symmetry is a diagonal line that divides the field into two equal segments).

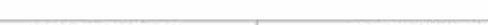

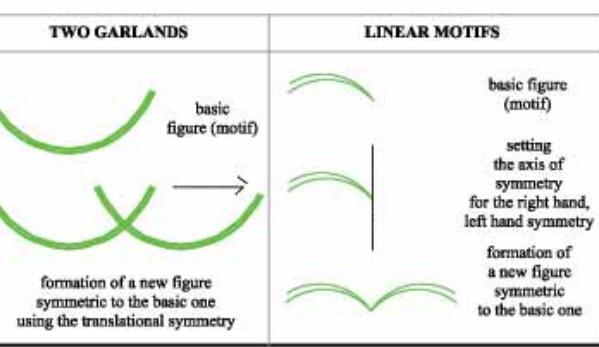

Fig. 16. Symmetries of the scenes with peacocks in the tomb G 2624.

(Schemes by Emilija Nikolić) 

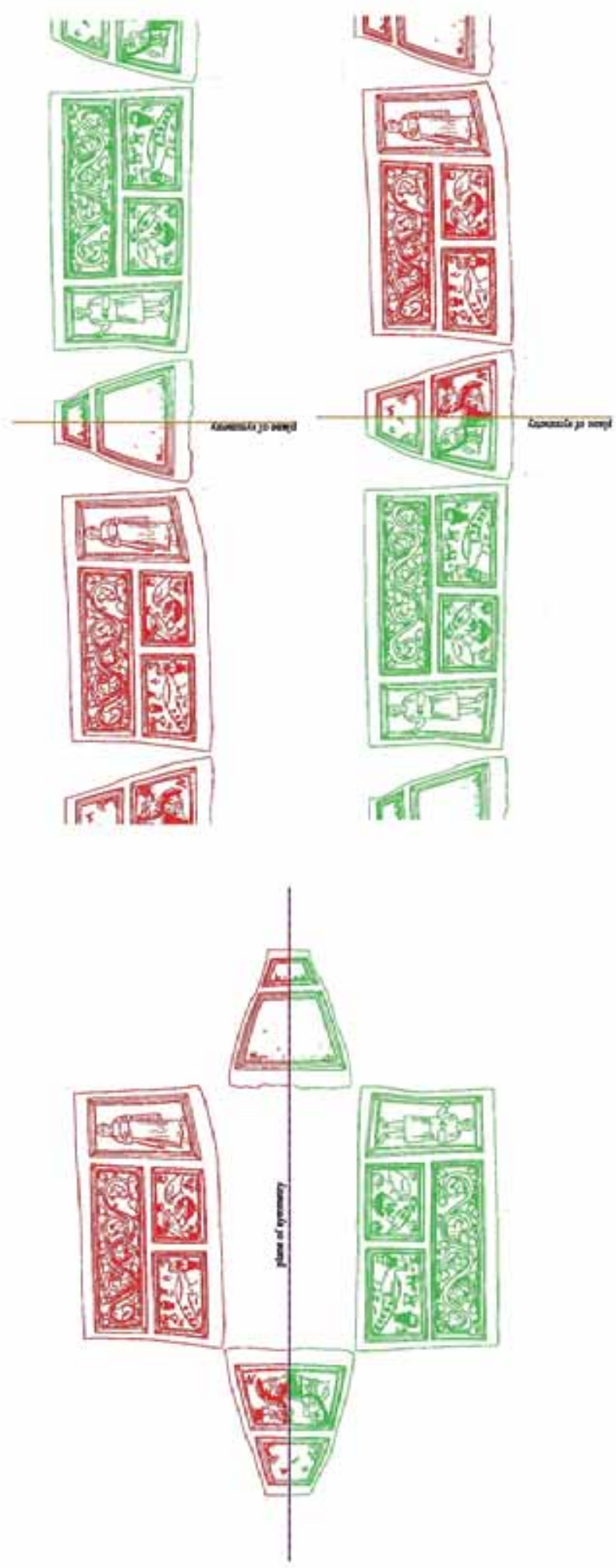

Fig. 17. Symmetry of the tomb's space in G 160 . (Schemes by Emilija Nikolić) 

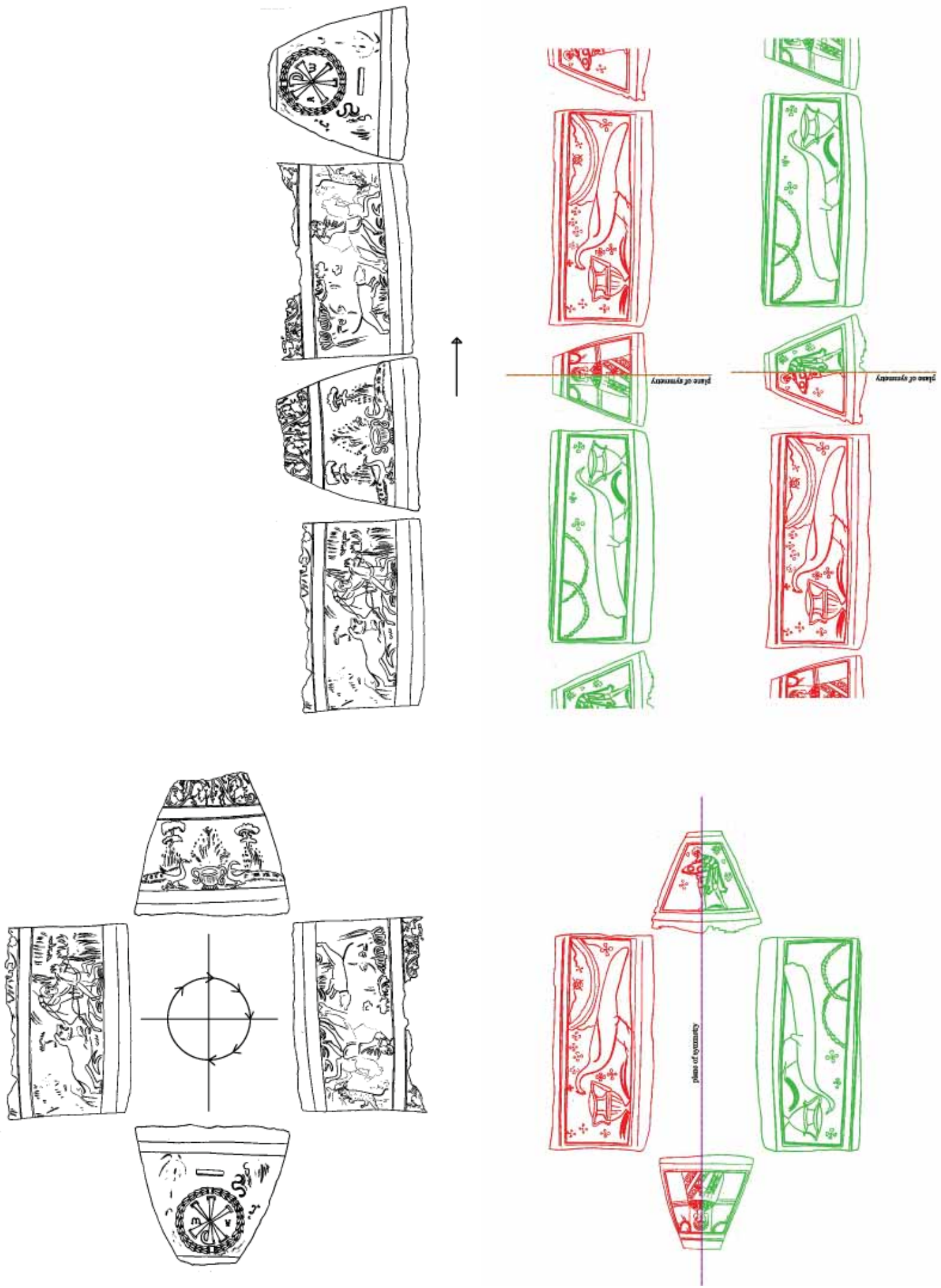

Fig. 18. Symmetry of the tomb's space in G 5517. (Schemes by Emilija Nikolić)
Fig. 19. Symmetry of the tomb's space in G 2624. (Schemes by Emilija Nikolić) 